Diego Arias (World Bank), Pedro Abel Vieira (Embrapa), Elisio Contini (Embrapa),

Barbara Farinelli (World Bank) and Michael Morris (World Bank)

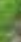

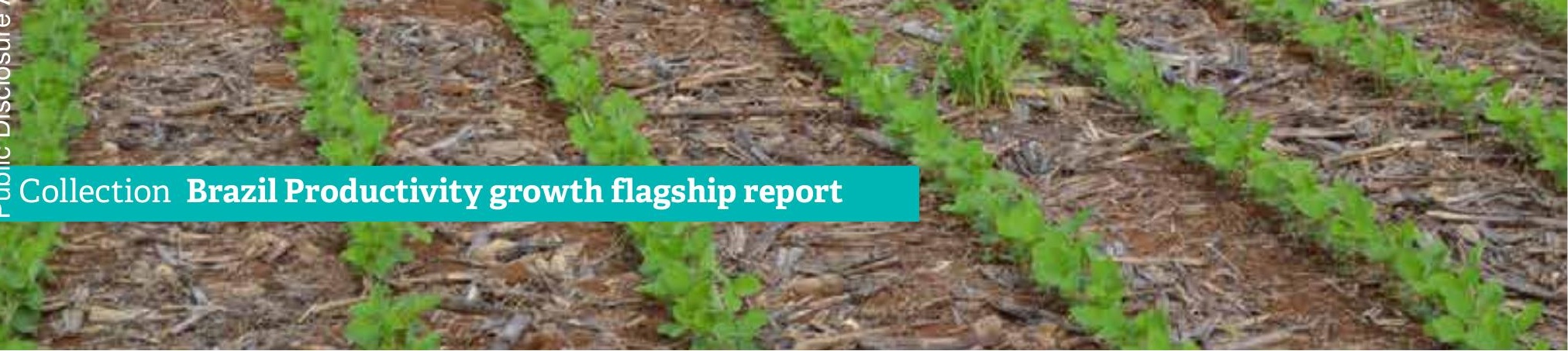




\section{BRAZIL PRODUCTIVITY GROWTH FLAGSHIP REPORT Agriculture Productivity Growth in Brazil}

Diego Arias (World Bank)

Pedro Abel Vieira (Embrapa)

Elisio Contini (Embrapa),

Barbara Farinelli (World Bank)

Michael Morris (World Bank) 


\section{CONTENTS}

\section{ACRONYMS 5}

\section{KEY MESSAGES 7}

\section{ACKNOWLEDGMENTS 11}

\section{SECTION 1. INTRODUCTION AND MOTIVATION 17}

Low productivity growth is impacting Brazil's economic growth

Productivity growth in Brazilian agriculture has been an island of success

SECTION 2. EVOLUTION AND SOURCES OF AGRICULTURE PRODUCTIVITY GROWTH

From food net importer to food net exporter and global agriculture trade leader

Agriculture productivity growth differs among farm sizes and regions

Agriculture productivity gains driven by technical change

Agriculture productivity growth helped by trade liberalization

\section{SECTION 3.USE OF FACTORS OF AGRICULTURE PRODUCTION 41}

Natural Capital

Human Capital

Physical Capital

\section{SECTION 4. IS BRAZIL MAXIMIZING AGRICULTURE GROWTH OPPORTUNITIES? 57}

Natural Capital

Human Capital

Physical Capital

SECTION 5. CONCLUSIONS AND POLICY RECOMMENDATIONS 57

Advancing the agriculture productivity frontier in a sustainable way

Closing the agriculture productivity gap for those left behind

Exploiting opportunities to generate more and better jobs

REFERENCES 75

\section{Figures}

Figure 1. Contribution of TFP to GDP Growth in Selected Countries 2000-2008 10

Figure 2. Evolution of Productivity by Sector, 2000-2013

Figure 3. Policy drivers in the agriculture and agrifood sector

Figure 4. Price of the Basic Food Basket in the Municipality of Sao Paulo, Brazil.

Figure 5. Agriculture TFP annual growth rate (\%)

Figure 6. Livestock TFP annual growth rate (\%)

Figure 7. Agriculture TFP Growth, 2001-2009 (average annual growth rate in \%)

Figure 8. Agriculture productivity growth in Brazil

Figure 9. Impact on Agriculture TFP of a $\%$ increase in different agriculture policies (elasticity)

Figure 10. Total Factor Productivity Decomposing by Farm Size in Brazil (1985-2006) (\% per year) Figure 11. Evolution of Total Support Estimate (TSE) in Brazil (2000-2012)

Figure 12. Composition of General Support Services Estimates (GSSE), 2012 or latest estimate Figure 13. Brazilian agriculture trade balance

Figure 14. World agriculture imports (2016) and share of the main agriculture

exporters and projections to 2000 (Trademap, 2017)

Figure 15. Trade in agribusiness and other sectors in Brazil (US\$ billions, 1989-2016)

Figure 16. Capital, land, and labor index for Brazil's agriculture sector

Figure 17. GHG Emissions- Brazil - 1990-2014 (CO2eq)

Figure 18. Variation in agriculture productivity in Brazil across regions (2006)

Figure 19. Harvested Area (has), Production (MTs), and Productivity (Kg/ha) of basic

grains (rice, soy, wheat, maize and beans) in Brazil.

Figure 20. Evolution of meat production $1975-2017$

Figure 21. Natural capital and TFP (MFP) productivity growth

Figure 22. Heads of Cattle vs. Pasture Land in Brazil

Figure 23. Distribution of the cattle (heads of) in Brazil

Figure 24. Global trends in shares of labor in agriculture and agriculture GDP in total GDP

Figure 25. Job creation and destruction in agriculture (1985-2007)

Figure 26. Occupational structure in the Brazilian economy

Figure 27. PISA assessment of 15-year old students' performance in mathematics,

reading and science (2012) - Mean performance scores

Figure 28. Agriculture Productivity indexes for Brazi

Figure 29. Rural credit availability in Brazil

Figure 30. Regional distribution of rural credit

Figure 31. Distribution of earmarked vs. non-earmarked by sector, firms credit,

December 2015 


\section{LISTA DE ABREVIATURAS}

Figure 32. Global competitiveness index: infrastructure (1-7 scale, higher indicates greater competitiveness)

Figure 33. Main imported agriculture products by the world by supplier country (Brazil vs. The rest, 2016) (Trademap, 2017)

Figure 34. Evolution of phosphorous in the soil of agriculture lands in Rio Verde, Goias, Brazil

Figure 35. Soy productivity response to phosphorous fertilizer (lands in Rio

Verde, Goias, Brazil)

Figure 36. Doing Business Ranking and Logistics Performance (2016)

Figure 37. Import tariffs for industrial and agriculture goods1 (2012 or latest available year)

Figure 38. Leased or sharecropped land area in Brazi

Figure 39. Land tenure 2000 (agriculture area, \%)

Figure 40. Sugarcane productivity vs. output under leasing or sharecropping 45

Figure 41. Amazon deforestation: relative participation by polygon size (2002-2011)

Figure 42. Accumulated deforestation and remaining native vegetation in

Brazilian biomes

Tables

Table 1. Labor, land and technology contribution to agriculture growth. Brazil

(1995-96 to 2006)

Table 2. Impact of degraded lands in agriculture TFP estimates for Brazil

Table 3. Formal jobs in the Brazilian agribusiness 34

Table 4. Economic activity and land use in Brazil, by size

Table 5. Brazil: Farmers' Cost Structure 38

Table 6. Differences in labor productivity between Brazil and other countries 42
Low Carbon Agriculture (in Portuguese)

National Agency for Technical Assistance and Rural Extension (in Portuguese) Brazilian Development Bank

Brazil, Russia, India, China and South Africa countries

Rural Land Cada

Carbon Dioxide

National Food Supply Company (in Portuguese)

Climate Smart Agriculture

Brazilian Agricultural Research Corporation

Food and Agriculture Organization of the United Nations

Gross Domestic Product

State Management Groups (in Portuguese)

Greenhouse gases

General Support Services Estimates

Heads per hectare

Brazilian Institute of Geography and Statistics (in Portuguese)

Integrated livestock crop forest system (in Portuguese)

National Institute for Space Research (in Portuguese)

Intellectual Property

Land use Change and Forestr

Ministry of Agriculture, Livestock and Food Supply

Ministry of Environmen

ato Grosso do Sul State

Million tons of Carbon Dioxide Equivalent

Non-Governmental Organization

National Policy for Climate Change (in Portuguese)

Organization for Economic Co-operation and Development

Total Factor Productivity

otal Support Estimate

United Nations Framework Convention on Climate Change

United State Department of Agriculture

Agroecological Zoning (in Portuguese) 


\section{KEY MESSAGES}

- Agriculture has been an island of success in terms of productivity growth in the last decades compared to other sectors of the Brazilian economy and compared to other country's agriculture sector.

- Agriculture productivity growth in recent decades in Brazil has been mainly driven by investments in agriculture innovation, facilitation of sector financing, and trade liberalization.

- Trade liberalization has shown to be an important factor in the growth of agriculture productivity in recent decades, which can serve as an important experience for other Brazilian economic sectors that remain relatively close to trade.

- Policy reforms to promote strategic financing, agrologistics, and R\&D can improve agriculture productivity in lagging mid-size farmers and regions.

- Experience within Brazil shows that agriculture productivity can continue to grow without depleting natural capital nor further increasing GHG emissions.

- Brazilian agriculture productivity growth has been a net job creator, unlike other sectors (and countries) that have seen a structural economic transformation

- Agriculture productivity growth in Brazil can therefore continue its positive upward trend, while being environmentally sustainable, creating jobs, and increasing incomes for the rural poor.

\section{ACKNOWLEDGMENTS}

We would like to thank the valuable input provided by the authors of several background papers, Jose Eustaquio Riveiro (IPEA), Jose Garcia Gasques (MAPA), Vinicius de Melo Benites (Embrapa), Junior Garcia (Universidade Federal do Parana), and Roberto Giolo (Embrapa). We would also like to recognize with gratitude the advice and helpful comments provided by Steven Helfand (UCR), Octavio Damiani (IADB), Mark Dutz (World Bank), Martin Raiser (World Bank), Michael Toman (World Bank), Paulo Camuri (CNA), and Jorge Araujo (World Bank). Finally, we thank Wanessa Matos for her support in producing this report. 


\section{INTRODUCTION AND MOTIVATION}

1. The industrialization process in Brazil begun in the 1960 and intensified in the 1970s, however the expected productivity growth of the overall economy and structural transformation did not happen. Since the end of the 1970s, the Brazilian labor productivity has been lower than many similar economies, currently representing around
$1 / 40$ of the average labor productivity in OECD countries. Moreover, the economic growth in Brazil observed in the 2000s - 0,3\% per year between 2002 to 2014 was not a consequence of labor procuctivity growth, but from increased of the manufacturing sector on the Brazilian GDP dropped from 18\% to about $11 \%$ between 1995 to 2014 while the service sector whose participation was less than 55\% in 1995, reached more than 65\% in 2014 (World Bank, 2016).

2. Between 2003 and 2010 , during a period when the overall Brazilian economy grew at a rate of 4 percent per year, less than 0.5 percentage points per year came from improvements in Total Factor Productivity (TFP). The bulk of this growth was attributed to increases in the labor force and in labor force participation. Over a slightly longer period 2002-2014, the contribution of TFP was even smaller, approximately 0.3 percentage points per year (World Bank, 2016. During this period, TFP growth in Brazil lagged significantly behind that of most other emerging markets (Figure 1).

Figure 1. Contribution of TFP to GDP Growth in Selected Countries 2000-2008

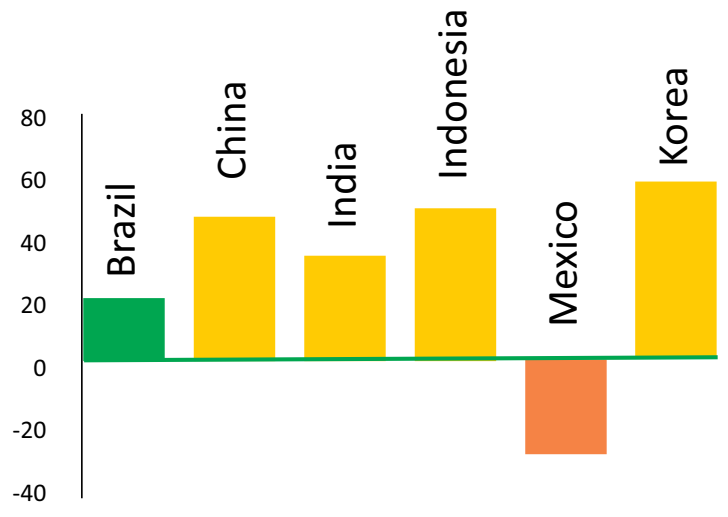

3. One of the reasons for the weak productivity performance of the Brazilian economy in the past decades has been the manufacturing sector. The increase in productivity of the Brazilian economy has been occurring only by the "intrasectoral effect", which means that productivity increases due to the increase in the aggregate productivity driven by the most productive sector, compared to the "intersectoral effect"(or structural change) that occurs when productive growth comes from different sectors than the traditional highly productive ones. Traditionally,
structural change happens when the primary agricultural sector becomes more productive (with technologies the save jobs) and ends "exporting" jobs t the manufacturing sector, which also ends up exporting iobs to the ses that sectors that is the last sector to develop and expand from increased jobs. In Brazil, during the last decade, the agricultural sector has been a net generator of employment (importing rather than exporting jobs to other sectors).

Productivity growth in Brazilian agriculture has been an island of success

4. Compared to agriculture, productivity growth in other sectors has been low. Over the past decade, labor productivity Coclinedin ag thenufecturing sector, stagnatedin the services sector, and incer (Figure 2). The movement of labor from primary agriculture to the other sectors (manufacturing and services) did
not contribute to increased productivity growth in the receiving sectors, in contrast to patterns in fast-growing (World Bank, 2017).

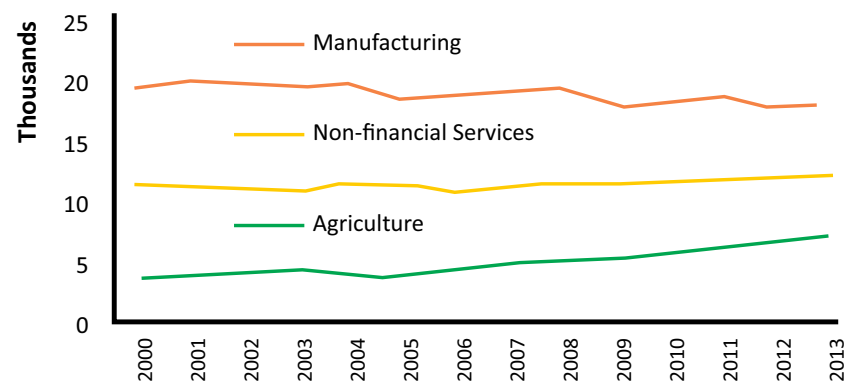

5. Between $2000-2013$, agriculture productivity rose by $105.6 \%$, compared to only $11.7 \%$ in the services sector and $-5.5 \%$ in the manufacturing sector. The impact of strong productivity growth in agriculture to overall productivity growt was significant, because even though agriculture accounts for only about $5.5 \%$ of GDP, the contribution rises to

6. The motivation for this report is to explore the evolution and source of the strong agriculture productivity growth that has occurred in Brazil in recent decades, identifying opportunities and challenges for future development of impact on sector growth, jobs, environmental sustainability, and poverty reduction, as well as potentially to shed light on lessons that can contribute to efforts to boost productivity in other sectors within Brazil.

7. The report is divided into five sections. Following this introduction, Section 2 describes the evolution and sources of agriculture productivity growth in recent years; Section 3 evaluates the contributions of different factors
of production, such as natural, human and physical capital; Section 4 explores the opportunities for further maximizing agriculture growth in Brazil through increases in productivity; and Section 5 presents conclusions an policy recommendations on how to further maximize agriculture productivity in Brazil while having positive social To a

8. To arrive at public policy recommendations for sustainable agriculture production growth, we use the OECD (2015) framework for improving agriculture productivity growth sustainably (Figure 3). The OECD framework lays out a set of public policy and incentive areas in which governments can intervene and draws attention to key drivers management (including actions taken to address climate change), and structural change. In this report, we will focus mainly on policies related to key production factors (such as human physical, and natural capital) and agriculture policies. Macroeconomic issues and barriers to the overall business environment (beyond agriculture) will not be addresse 


\section{EVOLUTION AND SOURCES OF AGRICULTURE PRODUCTIVITY GROWTH}

$\sum$ Policy areas $>$ Incentive areas $>$ Drivers of growth
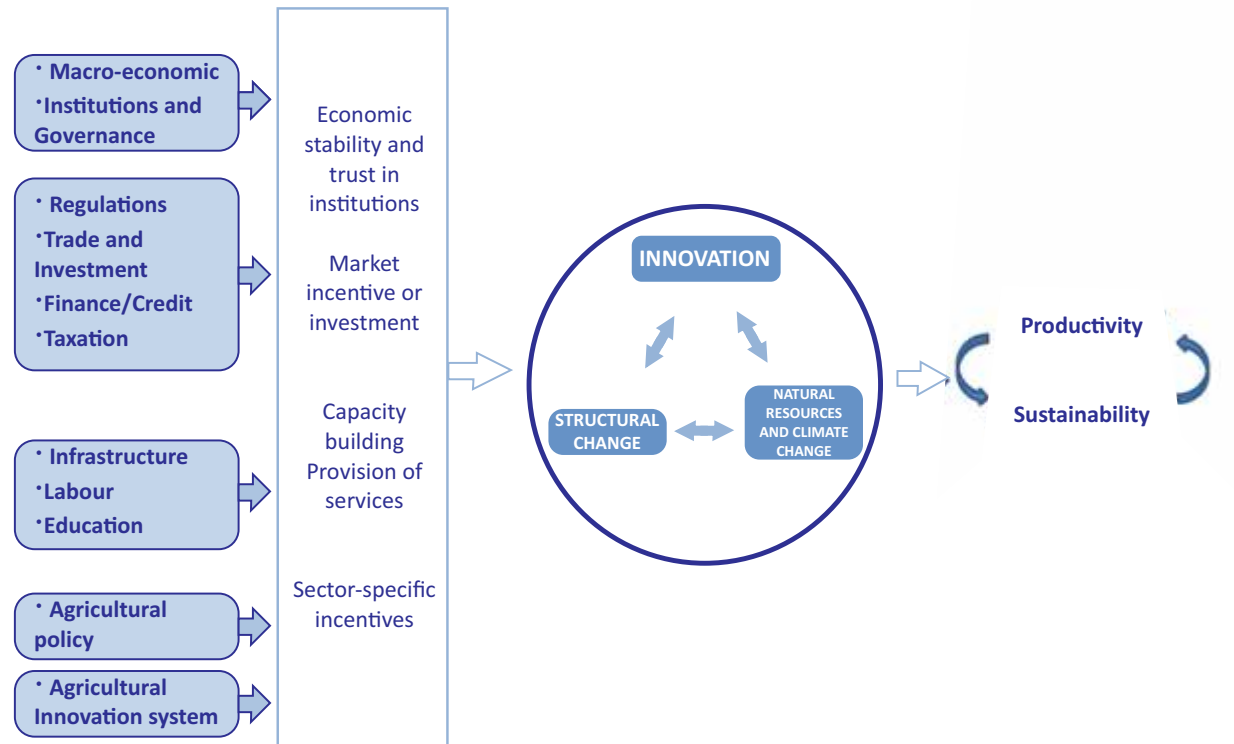

FROM EOOD NET IMPORTER TO FOOD NET EXPORTER AND GIOBAL AGRICUITURE TRADE LEADER

9. During the past three decades, Brazil's agriculture sector has grown at an impressive rate. Brazil has become the world s largest producer of sugarcane, coffee, tropical fruits, frozen concentrated orange juice, and it supports the cotton cocoa tobacco and forest products. Production increases have resulted in reductions in domestic real food prices between 1975 and 2000, in particular for items such as sugar, rice, banana, potatoes, coffee, beans, oranges, tomatoes, carrots, and lettuce (Barros, 2002). This reduction in food prices has also been accompanied by a reduction in food price volatility, not only benefiting the rural population, but large urban centers as seen in Figure 4 for the (s) Box 1$)$.

Figure 4. Price of the Basic Food Basket in the Municipality of Sao Paulo, Brazi.

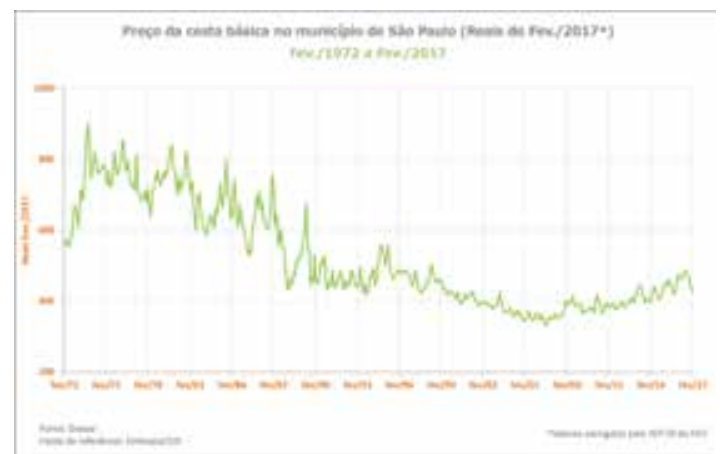

10. Total-factor productivity (TFP), also called multi-factor productivity, is a variable which accounts for effects in total output growth relative to the growth in traditionally measured inputs of labor and capital. If all agriculture inputs are accounted for, then toth foctor and other competitors when it comes to agriculture TFP growth. Both in the growth of its agriculure (Figure 5 ) and livestock (Figure 6) productivity, Brazil has had an excellent performance, especially considering the dismal productivity growth registered at a global level (Figure 7).

11. According to Gasques et al. (2012), agriculture TFP in Brazil increased by $109 \%$ over the past 25 years, fueling an increase of $232 \%$ in total production (animal and agricultural production), both driven mainly by adoption of new technologies and increased input use. ${ }^{\prime}$ Agriculture productivity growth has also led to significant increases in the value of agriculture production and in Brazil's food trade net balance.' Brazil's powerful export-oriented commercial

1 Ministerio da Agricultura and CONAB,

2 In 2014 , agricultural exports reached US\$ 96.75 billion, nearly $43 \%$ of the country's total exports, according to the Ministerio do Desenvolvimento, Secretari do Comércio Exterior 
Box 1 - Agriculture as a buffer against large economic contraction in Brazil

As Brazil undergoes a recession, agriculture stands out as the only sector growing amidst the collapsing manufacture and services

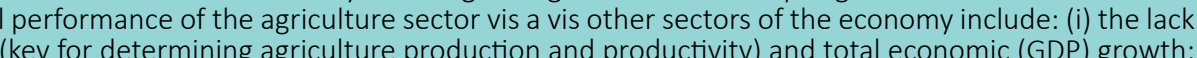
and (ii) the benefits of real exchange rate devaluation and depression of wages (which leads to more favorable conditions for agroexports and competitiveness). The latest figures show that while overall GDP contracted $3.8 \%$ in 2015 , the agriculture sector grew by $1.8 \%$.

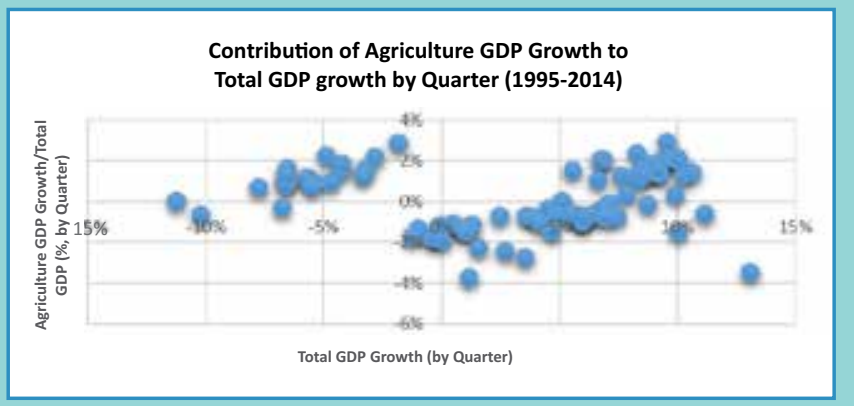

Source: Calculations by author based on IBGE Data.

The countercyclical performance of agriculture is not a recent phenomenon limited to the current recession. Data from the past two

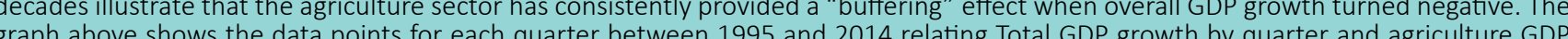
growth as a percentage of total GDP growth by quarter. Several interesting factors arise from these data points:

When Brazil's GDP contracts, the agriculture sector usually grows. The lack of data points in the bottom left-hand quadrant (with only a quarter ( $Y$ axis) is positive. This points out to a "buffering" effect of the agriculture sector in bad economic times. Were agriculture sector growth to behave procyclically, recessions in Brazil would be even worse. To clearly show this buffering effect, the graph below shows only the quarters when total GDP growth was negative between 1995 and 2014 . Out of the 24 quarters of negative total GDP growth, 17
show this buffering effect. If 2015 were to be added to the database (IBGE data extend only to 2014), then we would have an even larger proportion of quarters with the same countercyclical dynamic.

When Brazil's overall GDP growth is strong, agriculture GDP growth is also strong; but when overall GDP growth is weak (less than 政 performance and its agriculture sector performance. There is a procyclical relationship between total GDP growth and agriculture sector growth when total GDP grows above $5 \%$, while there is a countercyciclal relationship when total GDP grows between 0 and $5 \%$

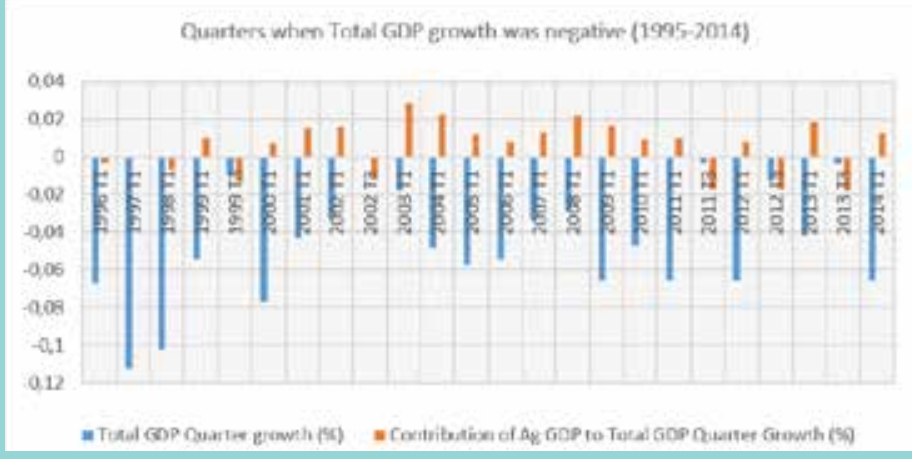

The fact that the agriculture sector plays a key role in Brazil's economy, especially during economic contractions, paradoxically reduces

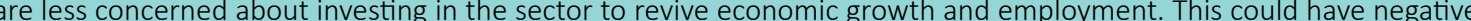
impacts in future, if the agriculture sector is left behind in terms of supporting its competitive position and acting as buttress for the strengthening of agriculture to ensure that future crisis do not produce even larger economic contractions. agribusiness sector supplies food and fiber to many countries that lack the capacity or ability to meet their did forty years ago Prior to the 1970s, Brazil produced a negligible amount of soybeans today it is the weans than it

Figure 5. Agriculture TFP annual growth rate (\%)

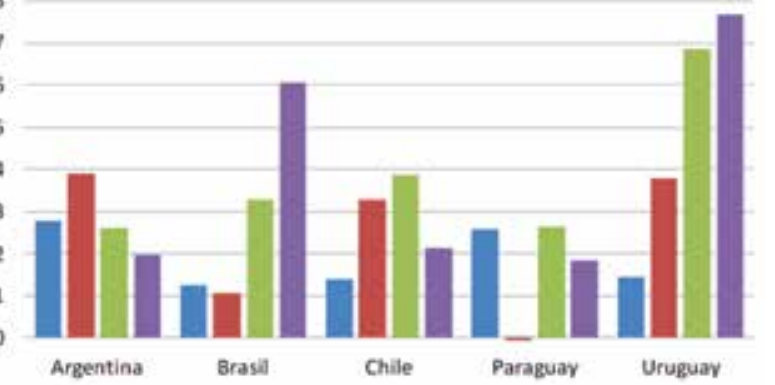

1961-1989 $=1990-2001=2002-2007 \approx 2008-2013$

Figure 6. Livestock TFP annual growth rate (\%)
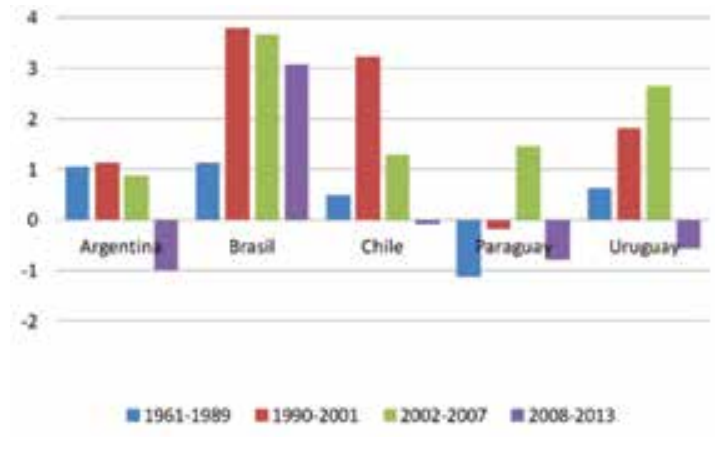

Figure 7. Agriculture TFP Growth, 2001-2009 (average annual growth rate in \%)

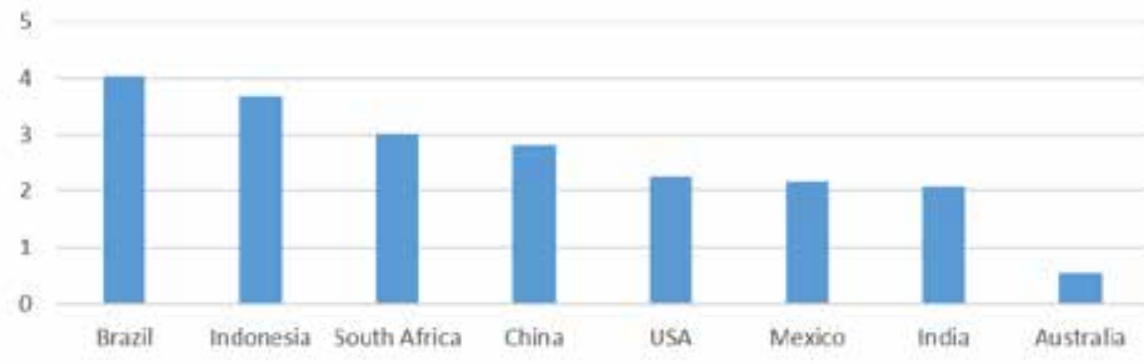


12. Since the 1970s, Total Factor Productivity (TFP) in Brazil's agriculture sector has increased at an average annual rate 3 $3 \%$. In 197\%, here was a positive structural break (there was a statistically significant increase in the growth rate) TFP growth and the pronounced acceleration starting in 1997 have been attributed to various factors: (i) the steady increase between 1970 until 1997 in agriculture public research expenditures through the Brazilian Agricultural Research Corporation (Embrapa); (ii) government promotion of agroexports and establishment of open agriculture trade policies; (iii) favorable agriculture credit policies and incentives; and (iv) macroeconomic stabilization policies introduced beginning in 1994

13. A recent study by Gasques et al. (2012) measured the impact of several of these policies on TFP. Figure 9 shows the positive impacts that agriculture exports (through an open agriculture trade policy), agriculture credit (through public sector incentives and earmarks), and agriculture research (through public investments via Embrapa') have agriculture public research expenditures led to increases (with various lags) in agriculture TFP by $0.14 \%, 025 \%$, and $0.35 \%$, respectively.

$$
\text { Figure 8. Agriculture productivity growth in Brazil }
$$

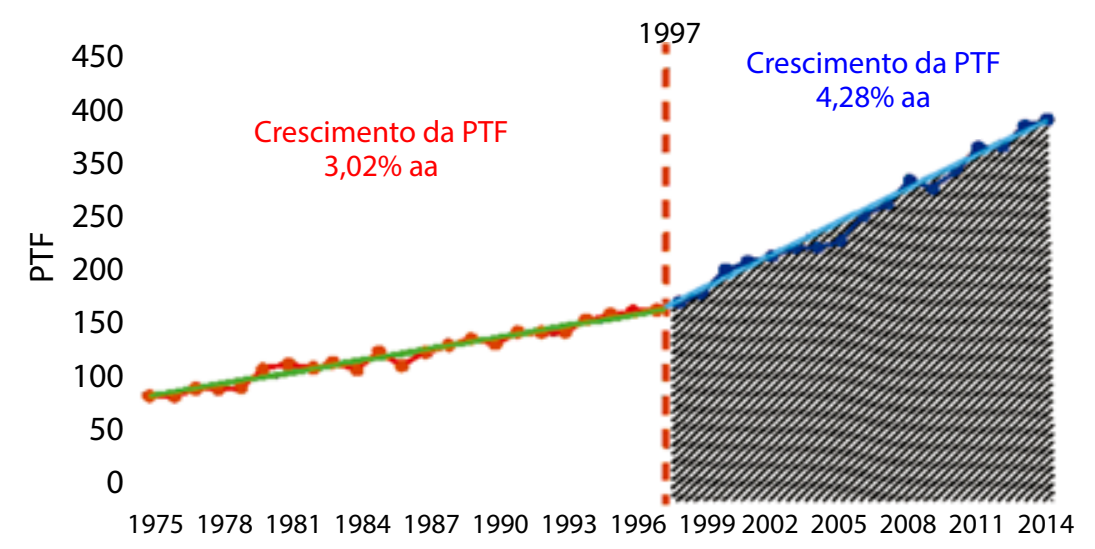

Figure 9. Impact on Agriculture TFP of a 1\% increase in different agriculture policies (elasticity)

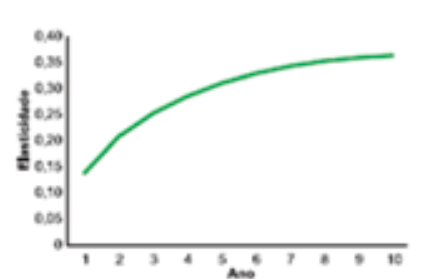

a. Embrapa agriculture research budget

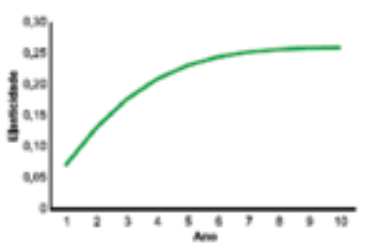

b. Public resource for rural credit

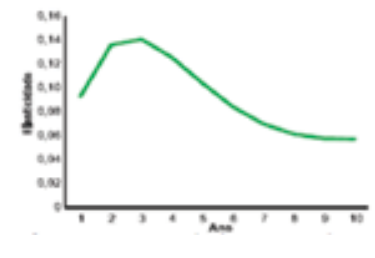

c. Value of Brazilian

agroexports
14. Although TFP growth has accelerated, driven by gains among the most efficient producers, the productivity gains have not been achieved by all producers, as the majority recorded mith 1985-2006, the farms that recorded the fastest annual average TFP growth were the smallest farms (0-5 ha) and the largest farms (500+ ha), with the former showing a small growth advantage. Interestingly, the relationship between productivity growth and farm size varied by region. In the North region, TFP growth declined with farm size, while in the Center-West region it increased with farm size, and in the South it mirrored the U-shaped national distribution. The Tre-farm size relationship was less cear-cut in the Northeast and Southeast. T-P appears to rise growth, whereas in the Southeast TEP growth was highest the $500+$ ha farm size class.

15. Mid-size farms (20-200 ha) have shown the lowest rates of TFP growth in recent decades (see Figure 10). According One hypothesis is that there are technologies that are more suitable for the smallest and larest farms. Large farms, for example, have led the expansion of the agricultural frontier in the Center West, where production of soybeans, corn, and cotton has increased rapidly in recent decades, thanks to heavy investments in machinery and technology. The boom has occurred mainly on extremely large farms, many of which comprise thousands of hectares. At the other end of the spectrum, small farms also have done extremely well, especially when they have been able to with accessing input and output markets. Institutions, in the form of contract farming or cooperatives have often played a critical role in these cases of success, which have involved livestock (chickens, pigs) and horticulture crops. among others. The second hypothesis explaining the lackluster performance of mid-size farms is that public policy has focused on the smallest and the largest producers, while to a certain extent ignoring those in the middle. A possible explanation is that agricultural policies and programs are implemented by two agencies with quite different

Figure 10. Total Factor Productivity Decomposing by Farm Size in Brazil (1985-2006) (\% per year)

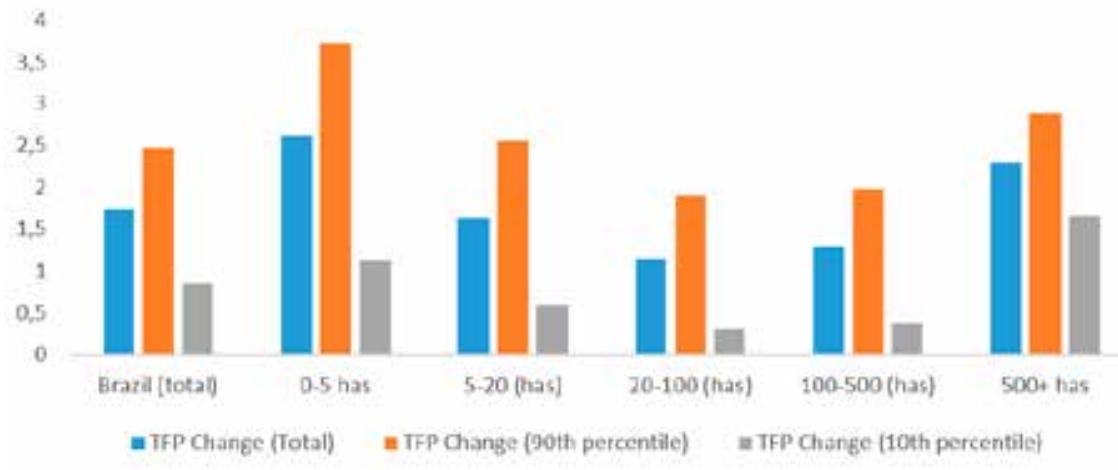

16. Farmer groups in Brazil are either associations or cooperatives. While associations have greater emphasis on representativeness, cooperatives seek economic advantages to the participants due to economies of scale. In employment in the last three years. In 2015 agricultural cooperatives exported a volume of U\$5 53 billion and more 


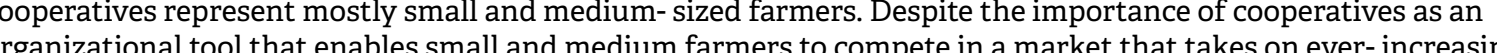
scales, the Brazilian cooperatives still face serious operational difficulties. Overcoming these difficulties, rangin from legal/regulatory to financing and management, could greatly increase the productivity of the Brazilian agriculture sector, in particular, the small and middle size farmers. It is these organized small and medium size farmers the ones that have the capacity to reduce transaction costs and to reunite several producers to compete

17. In 2016, the agribusiness sector (agriculture inputs, transformation, production and distribution) comprised nearly one-fifth of the national economy, contributing about $R \$ 1.5$ to the country's total GDP of approximately R $\$ 6.3$ trillion. Although the sector's contribution to total GDP has decreased somewhat over the past 10 years (falling from Agricultural growth has been unequal between and within regions, however, as growth has benefited mainly the small number of farms that earn more than 10 minimum salaries (approximately 500,000 farms, representing 11.4\% of the total). As per the last Agriculture Census (2006), the vast majority of farms that earn less than 10 minimum salaries (approximately 3.9 millon farms, representing $88.6 \%$ of the totall account for only $3.3 \%$ of the gross value of production and have largely failed to beneft from improved technologies and enhanced income opportunities agriculture policies and programs. Most of these farms are located in the Northeast Region.

18. Technology explained $68 \%$ of growth in agriculture value added in 2006, compared to only 50\% in 1996 (Table 1). Embrapa has played a key role in the development of Brazilian agriculture. The World Economic Forum's Global Competitiveness Report for 2012-13 rated Brazil 39th among 144 countries in terms of innovation. Innovation is often location-specific, as illustrated by the experience of the cerrado (Brazilian savannah) in the Central-West
macroregion. Up until the 1970s, relatively little agriculture was practiced in the cerrado, in part because there was no technology specific to agriculture in the cerrado, and productivity was low. Through sustained efforts, Embrapa was able to introduce agricultural technologies used outside Brazil and adapt them to the conditions of the Cerrado and that sparked a complete transformation of Cerrado agriculture.

19. Innovation in Brazil's agricultural sector benefited from conducive policies, especially policies targeting large-scale agribusinesses. Policies that ensured the ready availability of agricultural financing permitted purchases of same time, policies that guaranteed minimum prices for leading commodities reduced the risk carried by commercial producers. In spite of the impressive achievements, innovation bottlenecks persist, however, and further gains can be realized if these bottlenecks can be overcome. Improving infrastructure, resolving sanitary standards, paying to smallholders - have the potential to drive further productivity growth among a larger set of farming enterprises.

20. However, compared to other OECD countries, Brazil spends a relatively small percentage of investments in shown in the area of ariculture R\&D, mainly through its investments in Embrapa public spending Brazil hicultur innovation in Brazil currently makes up only $7.6 \%$ of total agriculture support in the country, and the share continues to decrease (Figure 11). Furthermore, public spending on agriculture innovation is $40 \%$ of total spending on agriculture public goods and services, while in other OECD countries the share ranges from 60 to $90 \%$ (Figure 12).

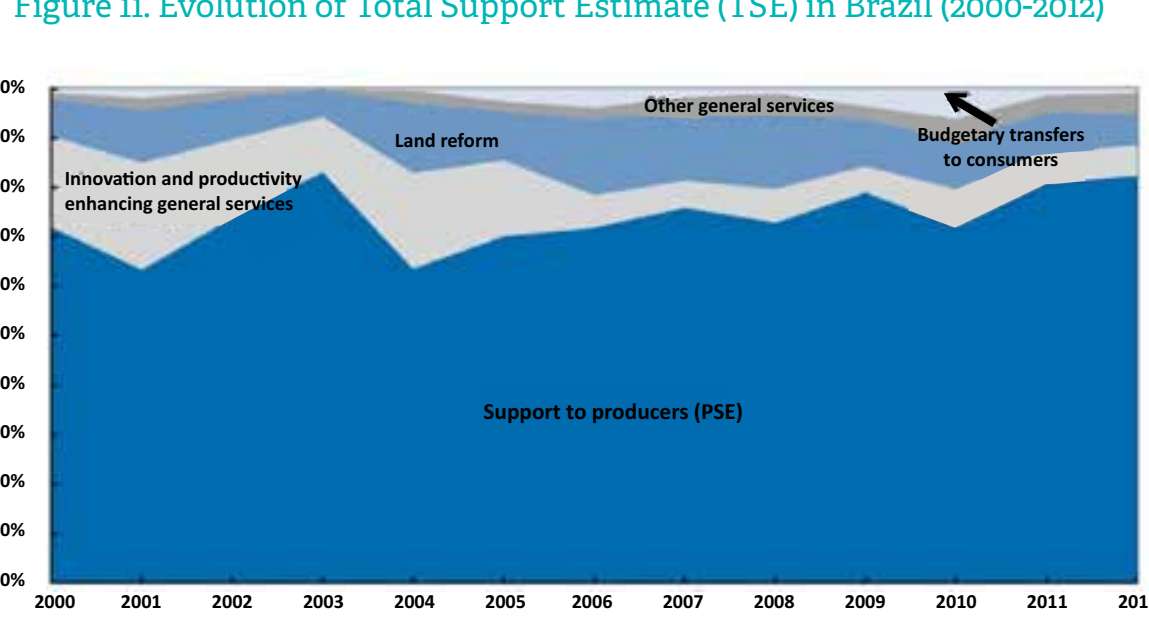

Figure 12. Composition of General Support Services Estimates (GSSE), 2012 or latest estimate

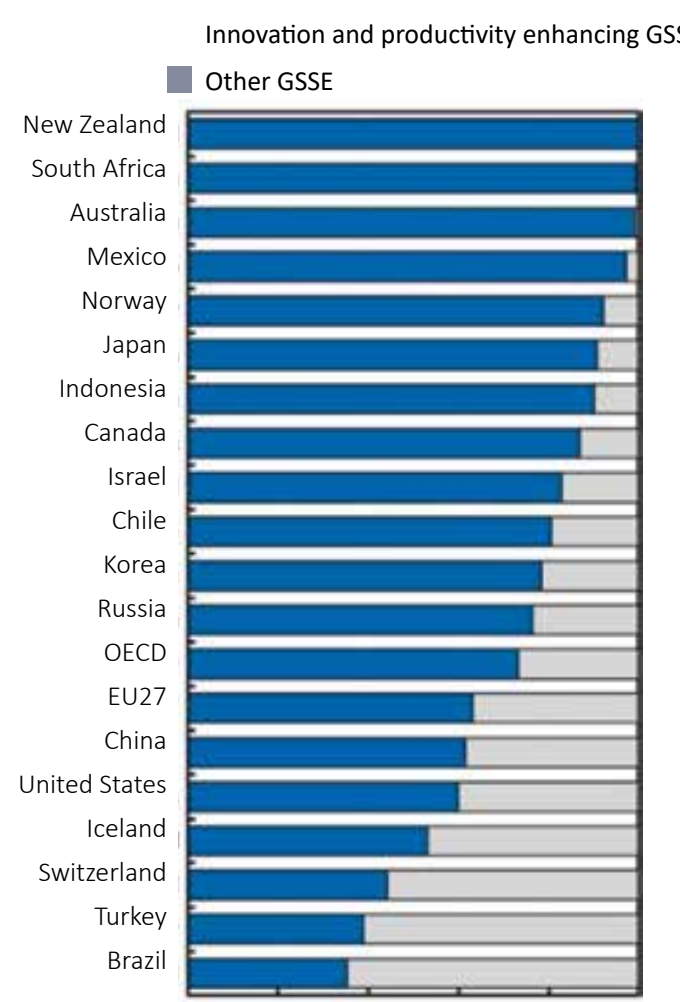


21. The growth of the Brazilian agriculture sector was led by international trade (Figure 13). However, after a period of enabling China to rank third in the global ranking of word agricultural trade in 2016 . The sitution is worrisome because Brazilian participation continues to decline, contrary to Chinese performance (Figure 14).

growth, however the relation

Figure 13. Brazilian agriculture trade balance

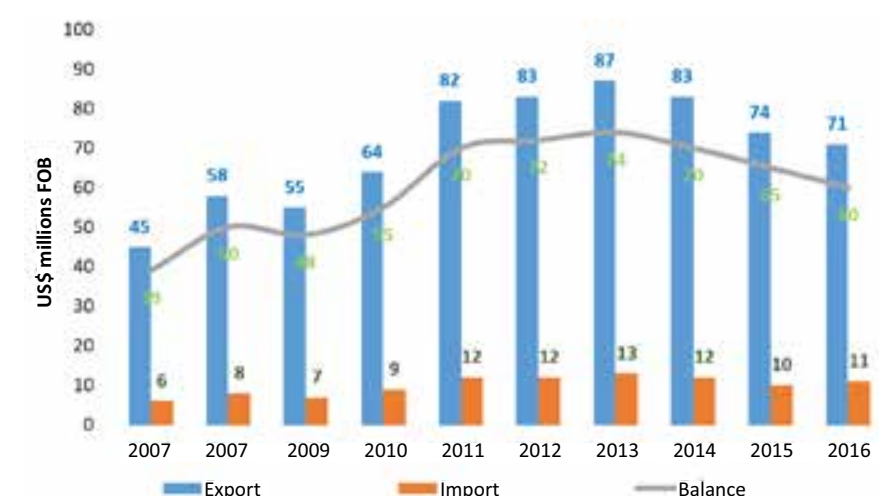

Figure 14. World agriculture imports (2016) and share of the main agriculture exporters and projections to 2000 (Trademap, 2017)

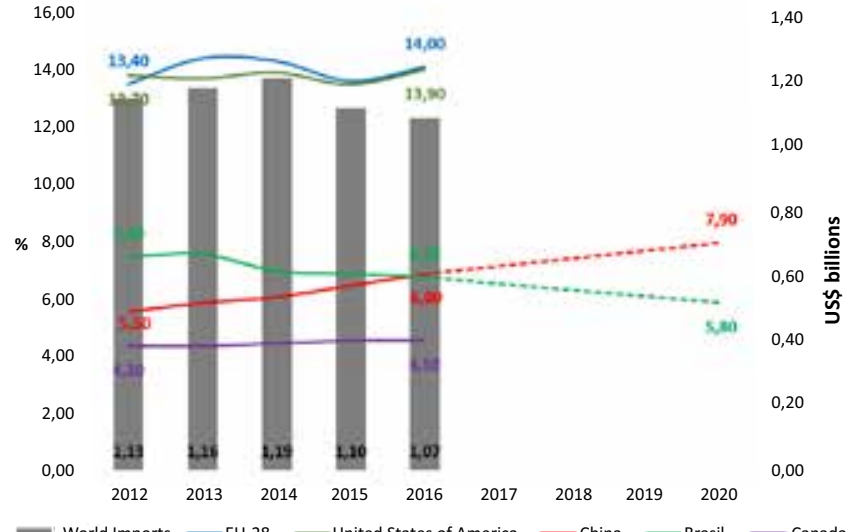

22. Trade liberalization measures introduced beginning in the early 1990 increased trade in agriculture outputs and inputs in relation to other sectors (Figure 15), boosting agroexports, enabling the import of state-of-the-art up to Foreign Direct Investments (FDI) in local agriculture technology companies. Around the same time, the

Government stopped directly controlling the prices of agriculture commodities such as sugar, coffee, wheat and

Figure 15. Trade in agribusiness and other sectors in Brazil (US\$ billions, 1989-2016)

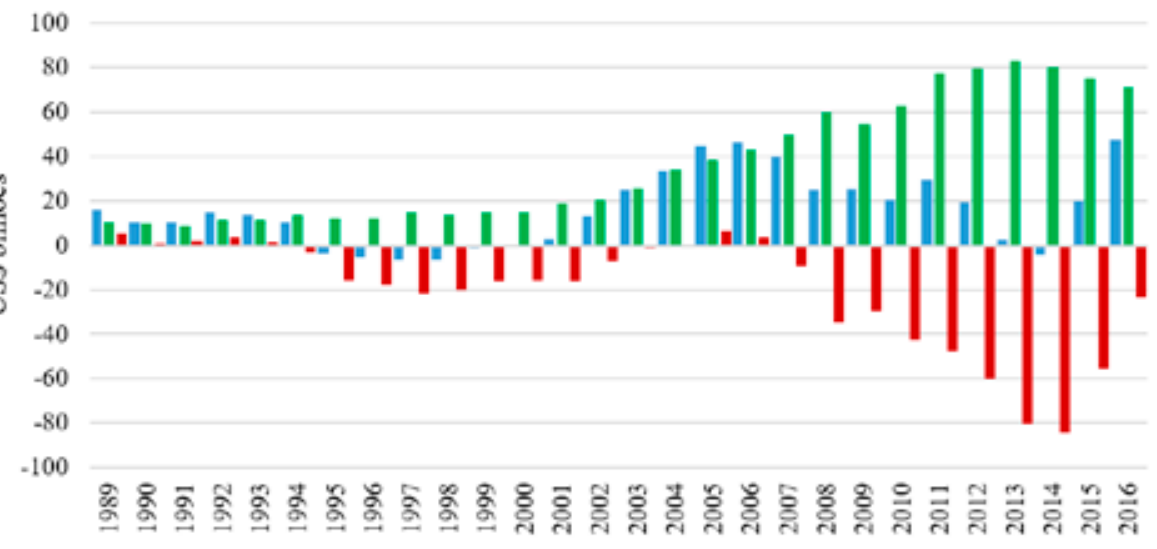

- Brasil "Arronegócio -Demais setores 


\section{USE OF FACTORS OF AGRICULTURE PRODUCTION}

23. Physical, human, and natural capital as factors of production are important targets of agriculture public policies and programs. Although their contribution to productivity growth has fluctuated in recent decades, physical, human and natural capital remain important in terms of their impact on social and environmental outcomes, since the affect employment, poverty, environmental services, and climate change. In Figure 16, land has remained stable increased and labor has decreased (signaling to the use of labor saving technologies and practices).

Figure 16. Capital, land, and labor index for Brazil's agriculture sector

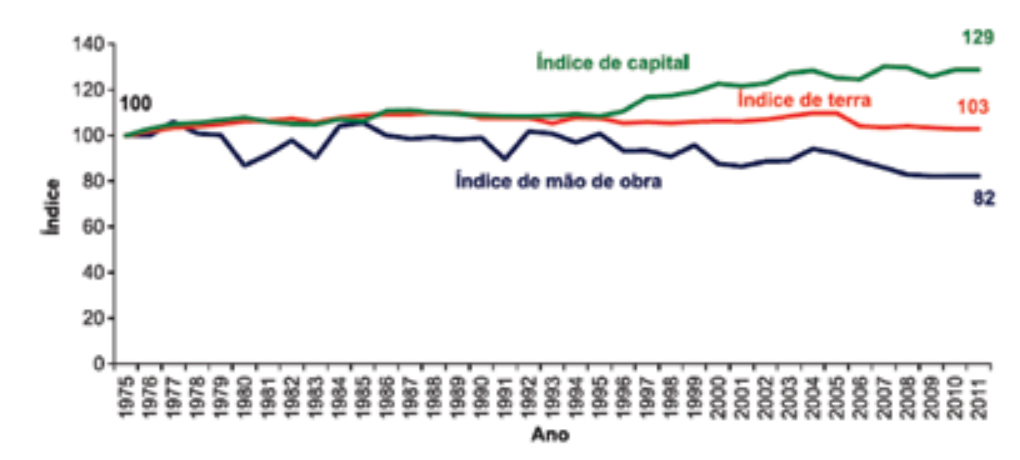

NATURAL CAPITAL

24. Brazil faces a major challenge in simultaneously pursuing agricultural growth, environmental protection, and sustainable development As a sobal leader on climate negotiations. Brazil has voluntarily committed to reducin greenhouse gas emissions by $36.1 \%$ to $38.9 \%$ between now and 2020. This will require a massive effort, as Brazil is one of the world's largest emitters of greenhouse gases (GHG). In 2010, Brazil emitted an estimated 52\% of Latin America's GHG emissions, representing around $7 \%$ of total global GHG emissions.

25. Enormous progress has been achieved in Brazil in slowing the cutting of the rain forest and other sensitive biomes, although more recently deforestation appears to be back in the rise since 2013." Brazil's forests and the cerrado represen an enormous carbon stock. The Amazon region, a reservoir of about 47 billion tons of carbon, sequesters more than five times the amount of carbon emitted globally each year. For much of the past century, he proctpal source of GHG Forestry (LUCF) activities, while agriculture was responsible for a relatively modest $20 \%$ of national emissions. This has now changed. Since 2004, substantial emission reductions have been achieved in the Amazon region, contributing significantly to the reduction of overall Land Use Change and Forestry (LUCF) emissions (Figure 17).

4 A recent article by the New York Times points out to a possible recent increase in the deforestation rate. https://Www.nytimes.com/2017/0/2/44/business/energy-environment/deforestation-brazil-bolivi

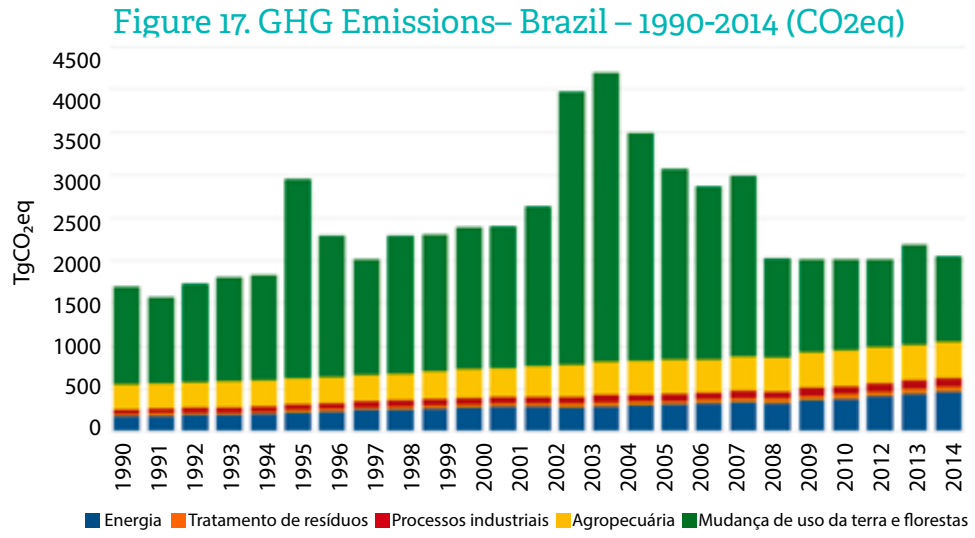

26. Agriculture has emerged as Brazil's main source of GHG emissions, accounting for an estimated $35 \%$ of total emissions. ${ }^{5}$ Going forward, the picture could worsen further. Conversion of forest land to agricultural uses is likely to continue in the Cerrado region, which contains very large areas with untapped agricultural and forestry potential. With the continuing expansion wiche

27. Geographical characteristics determine one-third of the variation in agriculture productivity across municipalities in Brazil (Helfand et al. 2015). In 2006, only $26 \%$ of Brazil's total land area was used for agriculture. Of this, onein Figure 16, agricultural productivity varies significantly across and within regions. One-third of the variability is explained by the region in which the farm is located, while the remaining two-thirds of the variability is explained by characteristics such as technical assistance, infrastructure, credit, etc. Therefore, even although agriculture productivity in the South and Southeast benefits from these regions' generally more favorable agro-ecological ecological conditions by using technology, inputs, and management to significantly increase their productivity.

Figure 18. Variation in agriculture productivity in Brazil across regions (2006)

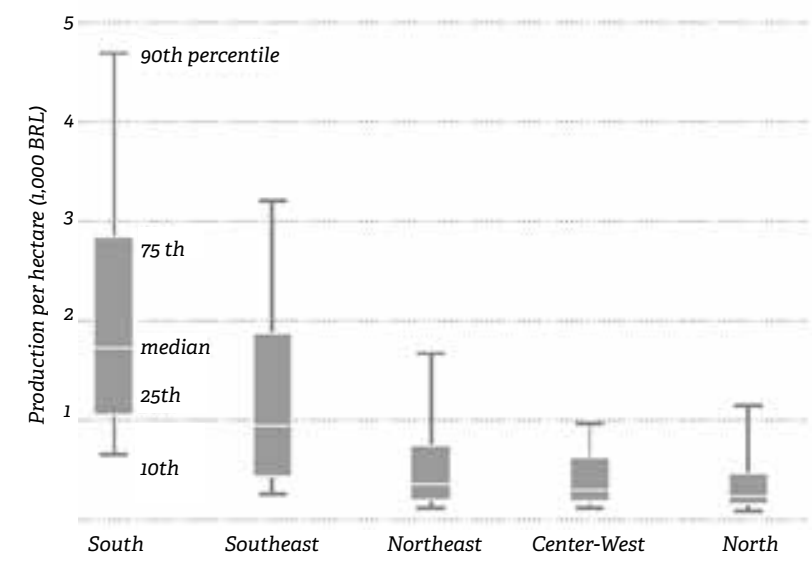


28. The area used for agriculture is still growing in Brazil, but expansion of the land frontier has significantly decreased in importance as a source of agricultural growth. In 2006, expansion in the area used for agriculture explained only intensive production systems - has been particularly apparent in the livestock sector which uses three-guarters all agricultural land (Figure 18). As seen in Figure 19, since 1975, land for agriculture production grew by 137\% while production of grains produced in that land grew by $982 \%$.

Table 1. Labor, land and technology contribution to agriculture growth. Brazil (1995-96 to 2006)

\begin{tabular}{|l|c|c|c|c|}
\hline \multirow{2}{*}{\begin{tabular}{l}
\multirow{1}{*}{$\begin{array}{l}\text { Selected } \\
\text { variables }\end{array}$} \\
\cline { 2 - 5 }
\end{tabular}} & \multicolumn{4}{|c|}{ Gross income growth } \\
\cline { 2 - 5 } & Coeficient & $\begin{array}{c}\text { Percentual } \\
(\%)\end{array}$ & Coeficient & $\begin{array}{c}\text { Percentual } \\
(\%)\end{array}$ \\
\hline Total & $\mathbf{0 . 8 3}$ & $\mathbf{1 0 0}$ & $\mathbf{0 . 9 4}$ & $\mathbf{1 0 0}$ \\
\hline Labor & 0.26 & 31.3 & 0.21 & 22.3 \\
\hline Land & 0.15 & 18.1 & 0.09 & 9.6 \\
\hline Technology & 0.42 & 50.6 & 0.64 & 68.1 \\
\hline
\end{tabular}

Source: Souza, G.S. et. al. Um modelo de produção para agricultura brasileira e importância da pesquisa da Embrapa In: Alves, E.R.A. Souza. G.S.: Gomes, E.G.

(Ed). Contribuição da Embrapa para o desenvolvimento da agricultura no Brasil

DF: Empresa Brasileira de Pesquisa Agropecuária - Embrapa, 2013. P. 47-86.

Figure 19. Harvested Area (has), Production (MTs), and Productivity (Kg/ha) of basic grains

(rice, soy, wheat, maize and beans) in Brazil.

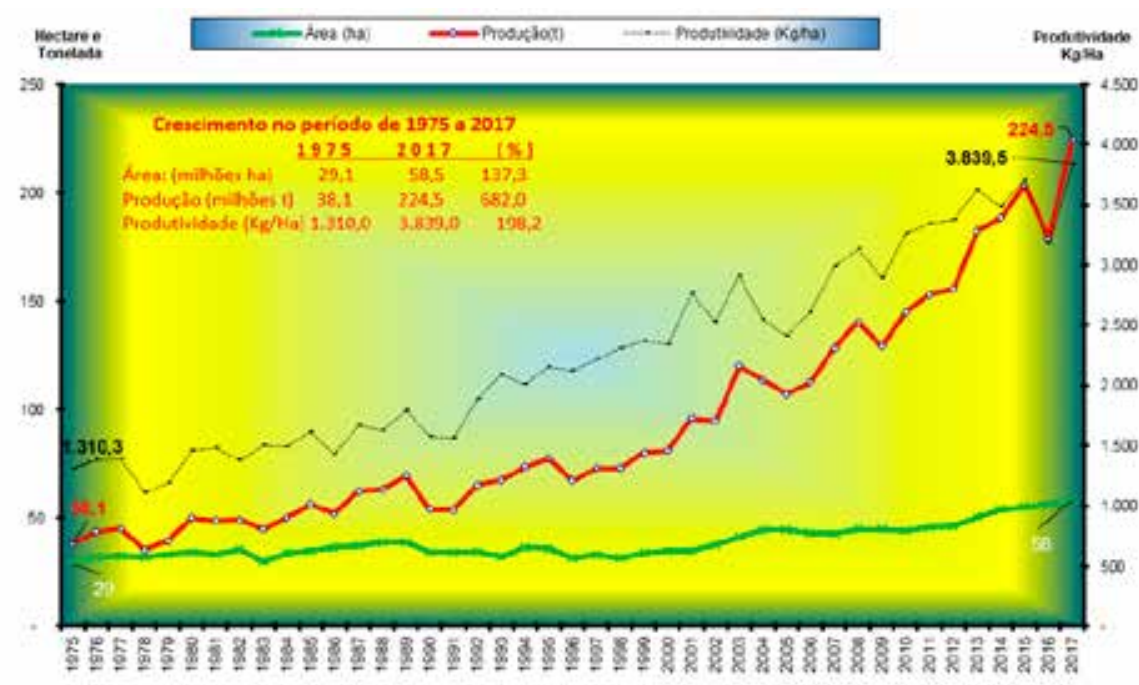

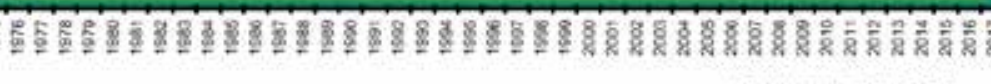

29. In addition to basic grains, Brazil has become a major producer and exporter of meat. From 1975 to 2016 , chicken meat production increased by 2,542\% from.0.52 million tons to 13.71 milion tonnes, pork from 0,8 million tonnes to 3,8 million tonnes (Figure 20). Furthermore, Brazil is a major producer of coffee, cotton, cocoa and forest products.
This sets Brazil as a key country to help feed the 95 billion people who will live on earth in the next 30 years. Brazt is today the world's largest exporter of coffee sugar orange juice and meats (beef and chicken): the so years. Brazil exporter of corn and soybeans (grains, bran and oil): and is an important exporter of of pork and cotton, among other agrifood items.

Figure 20. Evolution of meat production 1975-2017

\section{The expansion}

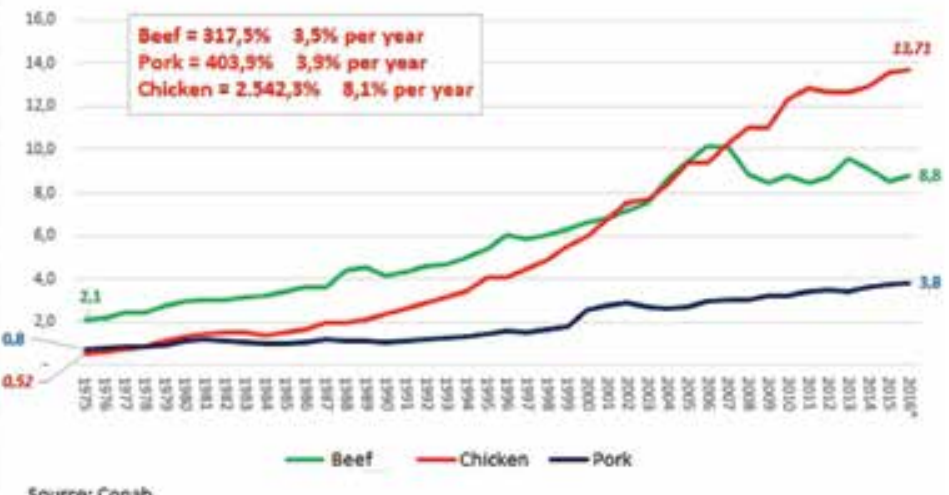

30. Despite negative environmental claims of the Brazilian agriculture sector, which mainly involves deforestation and and degradation, the sector has contributed to reduce the pressure on natural resources over the past decades. Over the last 25 years, production has grown by around $90 \%$, but thanks to technological innovations introduced - and increasingly taking into account environmental restrictions - the incorporation of new land was only $32 \%$. This trend should be accent

31. The Government of Brazil has started to introduce policies and programs designed to encourage the uptake of improved climate smart agriculture (CSA), such as conservation tillage (Box 2) and to promote the establishmen integrated crop-livestock systems with enhanced resilience to climate shocks (BoX 3). The Government is also US\$ 3 billion available for low interest credit for farmers willing to adopt CSA technologies. Finally, the buildup of agricultural soil carbon may also be eligible for carbon payments in voluntary and (future) formal markets. 32. Beyond the $\mathrm{ABC}$ program, Brazil has also introduced several policies and programs to face the reforms needed
to guarantee the production of food and to meet the ambitious environmental goals defined during the 68th UN Assembly. Such other policies and programs include: (i) the use of agroecological zoning, which will improve technological selection and reduce production losses and environmental risks; (ii) food labeling, (National Biosafety Policy), aimed at protecting biodiversity; (iii) the prohibition of burning of sugarcane after 2014; and (iv) the new

33. A critical question is whether the impressive productivity growth in Brazilian agriculture can be sustained. If

${ }_{6}^{6}$ Climate Smart Agriculture (CSA) is an approach that helps to guide actions needed to transform and reorient agriculture system to effectively support development and ensure food security in a changing climate. CSA tackles three objectives: (i) sustainably removing GHG where possible (FAO, 2016). 
The expansion of soybean production in the Brazilian Cerrado allows us to investigate to what extent innovation in agriculture drove land use changes at a time when policies were not addressing environmental issues land use change present during that period, such as the process of land occupation, changes in demand for .
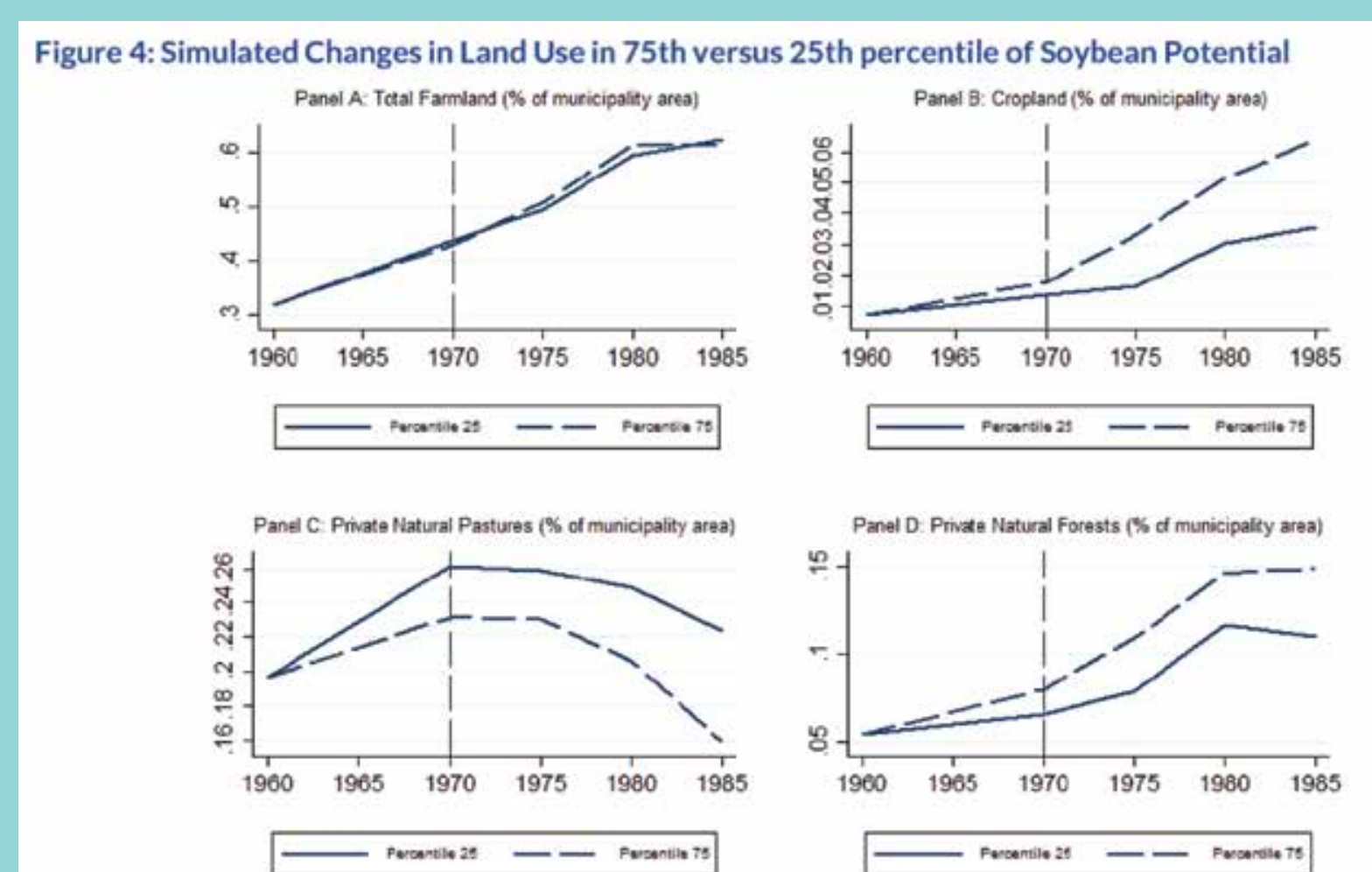

Note: The figure simulates the change in land use in a municipality in the 75 th percentile of the soybean potential distribution compored too wunicipality in the 25 th percentile of this distribution. The outcome variables are indicated in the panel tite. To simulate the change in land use, all distribution in the solid lines and in 75 th percentileo of the soy bean potential distribution in the dashed lines. Source (Braganca \& Assuncea, 2014) Source: (Broganco \&Assuncoo, 2014)

Figure 4 shows that, although there was no difference in the expansion of the total area used for agricultural purposes, land use within individual farms changed dramatically across municipalities with more and purposes, land use within ire frontier moved equally in both cases. However those municipalities more affected by the technical change increased crop land and reduced pasture land, with a net positive impact on natural forests inside private properties. These changes indicate that technological innovations impact farmers to expand agriculture in the intensive margin and invest in agricultural intensification, reducing the total area used for agriculture. They also indicate that tech decreasing the rate in which forests were cleared in Central Brazil.

This evidence suggests that, even when environmental goals are not an explicit priority, innovation in the agricultural sector is not associated with land expansion in a place facing the misallocation problems described in the previous section. The expansion observed in the Cerrado in that period is associated with other factors that also impacted the less affected municipalities. The isolated impact of innovation was beneficial with respect to economic growth and forest protection.

\section{Box 3 - Livestock, emissions and integrated systems}

Based on the latest Census of Agriculture, in 2006, nearly $75 \%$ of the country's agricultural land (about 160 million ha) was being used as pasture, and the remaining $25 \%$ (about 60 million ha) was being used for crop farming. Cattle ranching then was and today remains the most land-intensive agricultural activity in Brazil.

The productivity of cattle ranching can vary widely, however, even after accounting for geographic characteristics. Most variation in cattle ranch productivity is within regions. For example, while the top quarter of the Northern municipalities achieve more than 1.42 heads per hectare $(\mathrm{HPH})$, the bottom quarter is less than $0.7 \mathrm{HPH}$, more than a two-fold difference. Even in the region with the least variation in productivity, the Center-West, these thresholds are. 0.93 and $1.37 \mathrm{HPH}$, nearly $50 \%$ difference. While catle ranch productivity doubled between 1970 and potential for conversion of low-productivity pastureland into higher-productivity cropland.

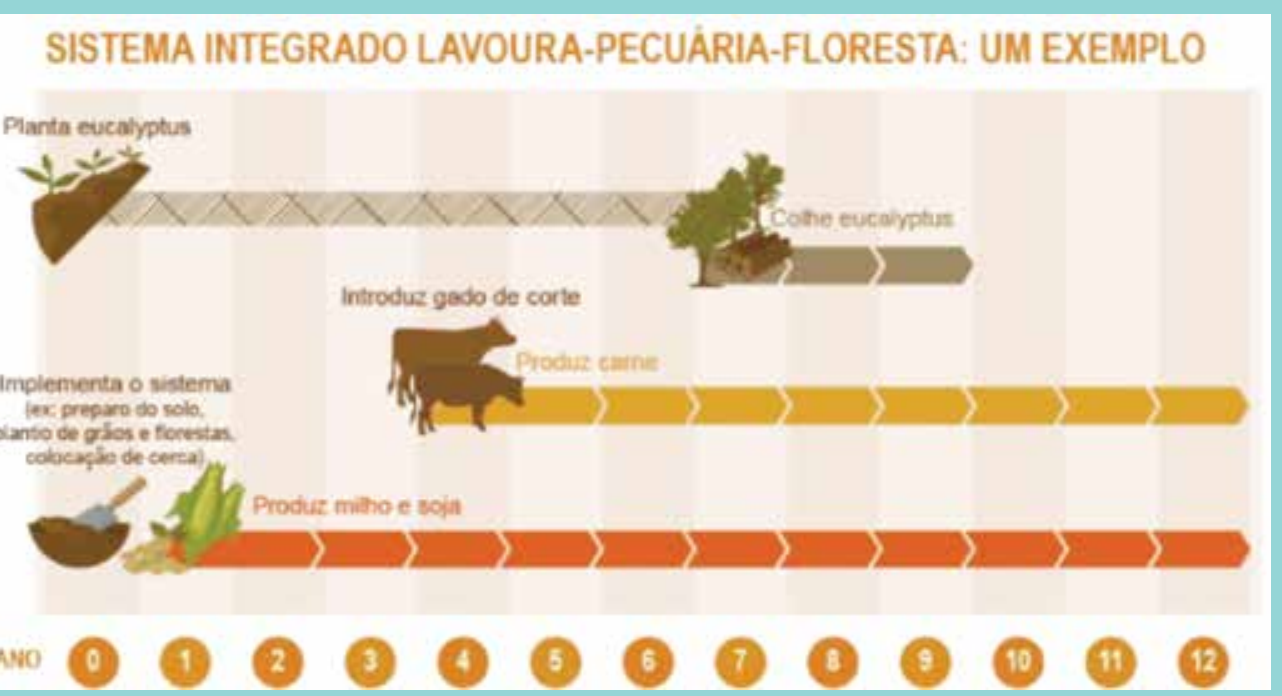

Whether current levels of productivity can be sustained is an open question, because a significant share of pasture land is classified as degraded, often to the point that it is no longer being used. which 11 milion hectares are in the Amazon. This would generate benefits in terms of carbon stock, $\mathrm{CO} 2$ emissions reductions, and an increase in biomass production, and would reduce the pressure for the conversion of new areas into grassland. Moreover, if the conversion is done to integrated sustainability, including carbon sequestration (see figure above). 


\section{Box 4 - Brazil's ABC Program}

In the context of the NPCC, the Ministry of Agriculture, Livestock and Food Supply (MAPA) developed the "Sector Plan for Mitigation and Adaptation to Climate Change for the Consolidation of a Low Carbon Emissions Agriculture Economy", also known as the ABC Plan. The overall objective of the in a riculture by improving efficiency in the use of natural resources, increasing the resilience in agriculture by improving efficiency in the use of natural resources, increasing the resilience of is expected to reduce pressure on forests by increasing agricultural productivity and promoting sustainable management practices.

ABC Plan Technologies. To achieve its objectives the ABC plan promotes six technologies that have proved effective in reducing GHG emissions and increasing carbon sequestration by the agriculture sector: (i) recovery of degraded pasture land; (ii) crop, livestock, forestry integrated systems (iLPF); (iii) no-tillage farming systems; (iv) biological nitrogen fixation; (v) cultivated commercial forests; and (vi) treatment of animal waste. The Brazilian

ggricultural sector has already initiated the adoption of some of these production technologies (such as biological nitrogen fixation and no-tillage) while also increasing productivity.

The ABC Plan credit line. The main financial instrument of the ABC Plan is a subsidized credit line for farmers, launched in 2010, to convert traditional agricultural practices to the above-mentioned ( level mainly due to lack of information and technical assistance for farmers. In 2011, with the approva of the $A B C$ Plan, actions were taken to accelerate implementation. Among other activities, Banco do Brasil became the main financial promoter of the ABC Plan credit line, and the State Management Groups (GGE) were created, with many public and private actors promoting the Plan through trainin and research. As a result, use of the credit line increased from $R \$ 418$ million in 2010/11, to $R \$ 1.5$ billion in 2011/12 and R\$3 billion in 2012/13 (or 88\% of the planned credit authorizations). In 2011/12 about 77 percent of the $A B C$ credits were provided for pasture recovery. Although farmers can obtain up to $R \$ 1$ million for agriculture and $R \$ 3$ million for commercial forest establishment, the average loan size is about R\$230,000 for an average land area of $105 \mathrm{ha}$. This suggests that producers are "testing" the credit line and the technologies on a limited portion of their properties.

Constraints for $A B C$ Plan technology adoption. $A B C$ technology adoption faces some additional hurdles. Most importantly, farmers lack knowledge and understanding of the technologies promoted. second, some technologies require strong farm management skills, and adequate training and technical assistance for farmers and ranchers. Finally, up-front costs for technology adoption are hig in some cases. The project design addresses a mid-size producer technological knowledge gap in order to speed up and improve the quality of adoption of ABC Plan technologies.

A final constraint is the lack of trained professionals to support innovation. The 2006 census data from IBGE indicate that nine percent of the farms in the Cerrado occasionally receive some form of technical orientation, while barely six percent receive technical assistance on a regular basis. Hence 85 percent of the farms do not receive any technical orientation. As the economic analysis (see below) demonstrates, the correct application of the technologies is imperative to assure farm economic and environmental sustainability. agricultural productivity growth in Brazil is being achieved at the cost of the natural resource base on which agriculture

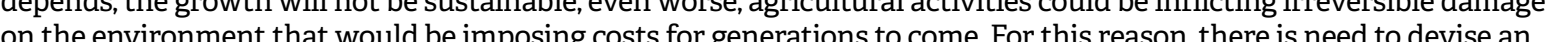
environmentally-adjusted measure of agricultural TFP that can be used to assess whether the impressive productivity growth recorded in recent years is depleting or conserving its natural capital base. Several attempts have been made to devise such a measure, but none appears capable of being operationalized at national level.

34. To provide insights into the relationship between agriculture TFP growth and the natural capital stock on which productivity growth depends, a conceptual framework is needed that can allow estimation of an environmentallyadjusted measure of TFP. Figure 21 presents such a conceptual framework. Recent case studies have attempted to relate agricultural productivity measures in general, and agricultural TFP in particular, to environmental factors such as soil quality and emissions, with the goal of generating evidence to allow empirical estimation of the one identifying degraded lands vs, non-degraded lands as factors of production and the second including GHG emissions as a negative output (damage) of the livestock production function.

Figure 21. Natural capital and TFP (MFP) productivity growth

Figure 3. Natural capital and multifactor productivity growth

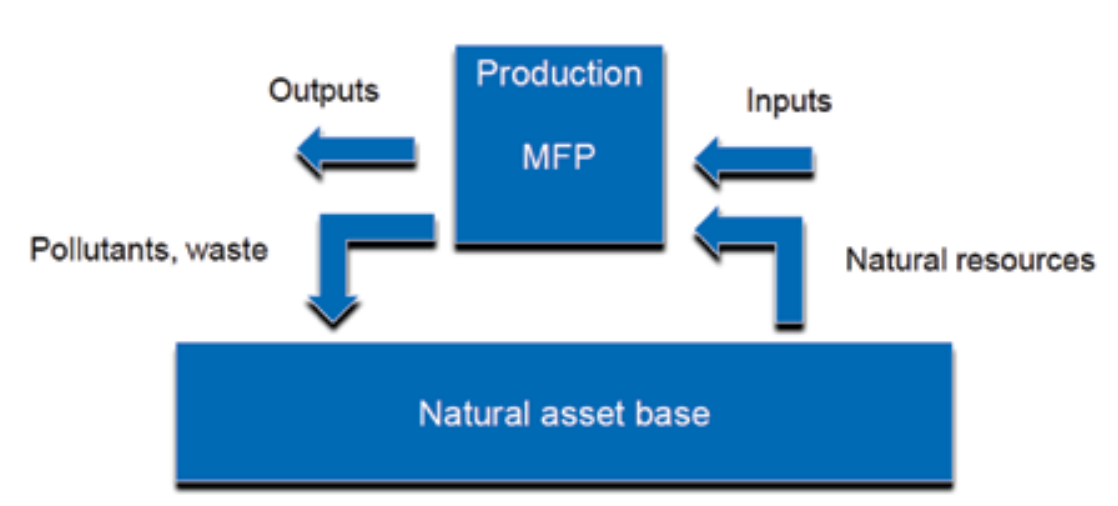

MFP: Mulifactor Productivity.

Source: adapted trom OECD (2014a and b).

35. Controlling for land degradation, agriculture TFP growth in Brazil remains positive, but the rate of growth is lower than the rate calculated using traditional measures of TFP (Gasques, 2017). Given that the use of degraded lands as a factor of production has had a higher growth rate than agriculture output during the period 2000-2015, the environmentally adjusted agriculture TFP growth rate that incorporates degraded lands is lower than the TFP growth measured without such environmental adjustment (Table 2). Using self-reported farmer data from IPEA,
degraded lands were identified as a separate input of production ()ver $6 \%$ of lands were reported to be degraded in degraded lands were identified as a separate input of production (over $6 \%$ of lands were reported to be degraded in
2015 estimates are considered conservative because many farmers do not consider land to be degraded until it is virtually nonates are considered conservative, because many farmers do not consider land to be degraded until could be larger, if more accurate measures of land degradation were available. 
Table 2. Impact of degraded lands in agriculture TFP estimates for Brazil

\begin{tabular}{|c|c|c|c|c|c|c|}
\hline \multicolumn{7}{|c|}{ Product, Inputs and Total Factor Productivity } \\
\hline \multicolumn{7}{|c|}{ Annual growth rate (\%) } \\
\hline PERIOD & 1975-2015 & 1975-1979 & 1980-1989 & 1990-1999 & 2000-2009 & 2000-2015 \\
\hline \multicolumn{7}{|c|}{ INDEX } \\
\hline PRODUCT INDEX & 3.85 & 4.35 & 3.38 & 3.02 & 5.18 & 4.38 \\
\hline INPUT INDEX & 0.26 & 1.74 & 1.19 & -0.10 & 1.06 & 0.38 \\
\hline PTF & 3.58 & 2.57 & 2.17 & 3.12 & 4.08 & 3.99 \\
\hline LABOR INDEX & -0.37 & 0.06 & 0.60 & -0.25 & -0.05 & -0.81 \\
\hline LAND INDEX & -0.02 & 0.72 & 0.29 & -0.32 & -0.22 & -0.16 \\
\hline CAPITAL INDEX & 0.65 & 0.96 & 0.29 & 0.48 & 1.33 & 1.36 \\
\hline \multicolumn{7}{|c|}{ PRODUCTIVITY } \\
\hline LABOR PRODUCTIVITY & 4.24 & 4.30 & 2.77 & 3.28 & 5.24 & 5.23 \\
\hline LAND PRODUCTIVITY & 3.87 & 3.61 & 3.09 & 3.35 & 5.41 & 4.55 \\
\hline CAPITAL PRODUCTIVITY & 3.18 & 3.36 & 3.08 & 2.53 & 3.81 & 2.99 \\
\hline \multicolumn{7}{|c|}{ (Assuming homogeneous land) } \\
\hline & & PTF & & 3.99 & & \\
\hline \multirow{2}{*}{\multicolumn{7}{|c|}{\begin{tabular}{c|c} 
Land productivity & 4.55 \\
Product, Inputs and Total Factor Productivity
\end{tabular}}} \\
\hline & & & & & & \\
\hline \multicolumn{7}{|c|}{ Annual growth rate (\%) (DEGRADED 6,189\%) } \\
\hline PERIOD & 1975-2015 & 1975-1979 & 1980-1989 & 1990-1999 & 2000-2009 & 2000-2015 \\
\hline \multicolumn{7}{|c|}{ INDEX } \\
\hline PRODUCT INDEX & 3.85 & 4.35 & 3.38 & 3.02 & 5.18 & 4.38 \\
\hline INPUT INDEX & 0.27 & 1.75 & 1.20 & -0.09 & 1.10 & 0.41 \\
\hline PTF & 3.57 & 2.56 & 2.16 & 3.11 & 4.04 & 3.96 \\
\hline LABOR INDEX & -0.38 & 0.06 & 0.61 & -0.25 & -0.05 & -0.82 \\
\hline LAND INDEX & -0.01 & 0.70 & 0.29 & -0.31 & -0.19 & -0.14 \\
\hline CAPITAL INDEX & 0.66 & 0.98 & 0.30 & 0.48 & 1.34 & 1.38 \\
\hline \multicolumn{7}{|c|}{ PRODUCTIVITY } \\
\hline LABOR PRODUCTIVITY & 4.25 & 4.30 & 2.76 & 3.28 & 5.24 & 5.24 \\
\hline LAND PRODUCTIVITY & 3.87 & 3.63 & 3.09 & 3.34 & 5.38 & 4.53 \\
\hline CAPITAL PRODUCTIVITY & 3.17 & 3.34 & 3.08 & 2.52 & 3.79 & 2.97 \\
\hline
\end{tabular}

PT

Prod. Terra
36. GHG emissions from livestock production in Brazil have increased, but more slowly than overall livestock production growth. Figure 22 shows the relationship estimated by Ribeiro (2017) between livestock and pasture land mainly due to the switching of pastures towards crop production. Furthermore. Figure 23 shows the clear increase in the numbers of heads of cattle from 1990 to 2000 in the Amazon and Cerrado biomes, but also shows a leveling-off between 2000 and 2015, reflecting a reduction in the pressure of livestock over natural resources and deforestation.

Figure 22. Heads of Cattle vs. Pasture Land in Brazil

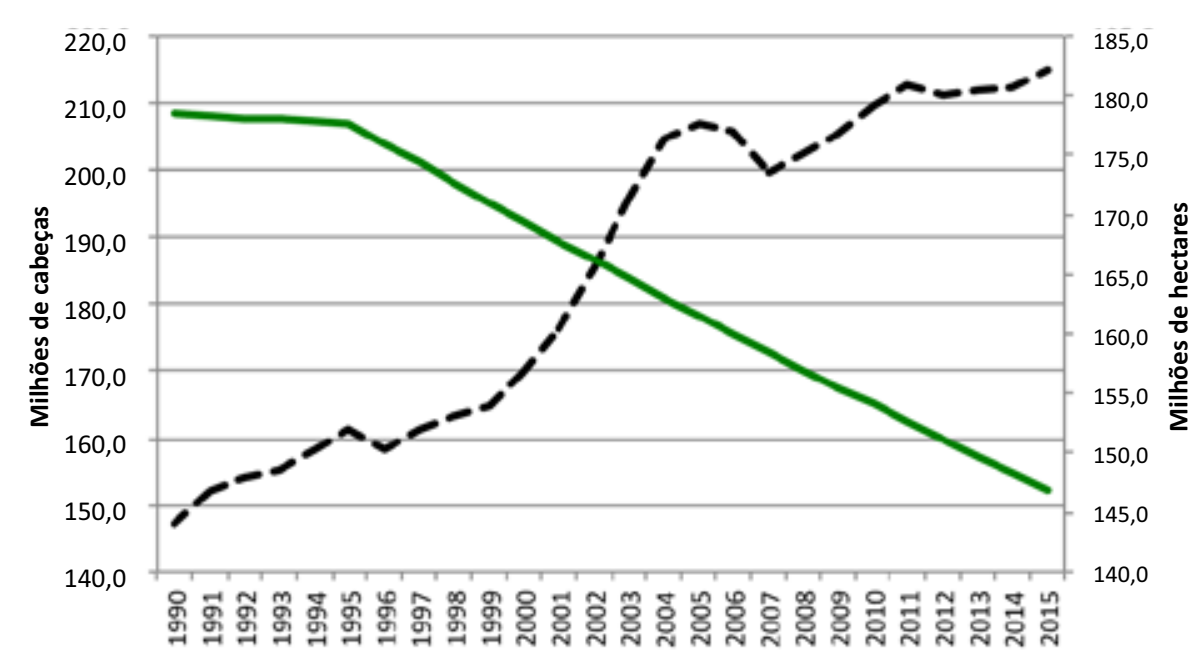

-. Efetivo bovino _- Area de Pastagens

37. Livestock is an important subsector within the agriculture sector, both in terms of value and in terms of land use and it is likely to become even more important in future given the expected increase in global demand for animal protein. In 2025. Over the same period the number of animals is projected to increase by $7.4 \%$ and meat production by $24.4 \%$. resulting in an 18\% reduction in methane emissions per unit of meat produced (Barioni et al., 2007). 


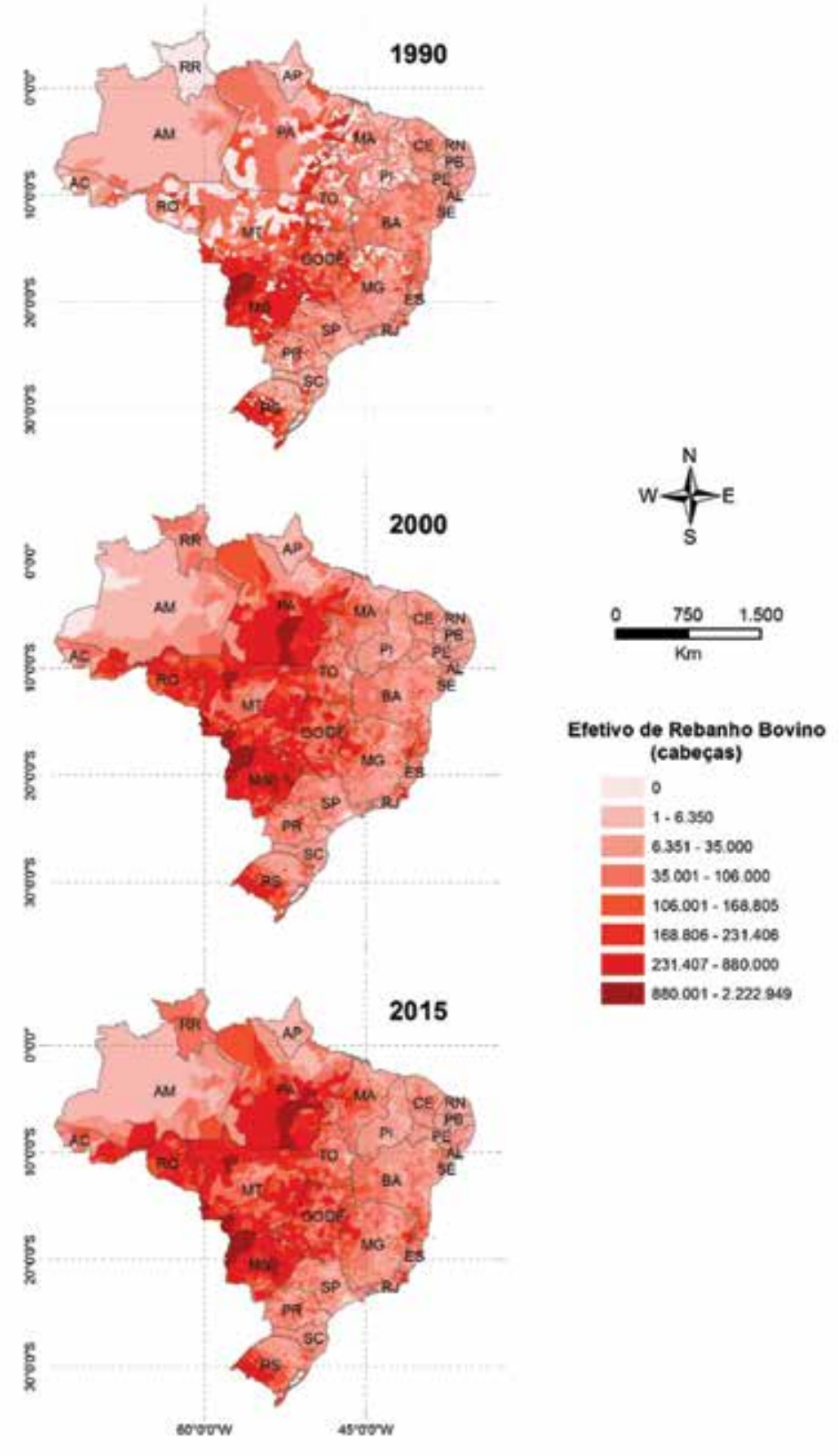

38. In Brazil, unlike in most other countries, development has been associated with a large net increase in agricultural employment. It has been widely observed across history that as countries develop, the share of agriculture in the economy and employment declines. This change is consistent with the idea of structural change. In economies in which income levels are still low, agriculture is typically the sector that employs the most people and uses labor relatively unproductively. Over time, cross-sector productivity gaps tend to shrink as labor shifts out of agriculture and returns to labor across sectors converge through factor markets (Figure 24). Brazils experience has differed agriculture sector was expanding rapidly and thus, the number of workers employed in primary agriculture the increased (Figure 25). When the definition of agricultural employment is expanded to include not only those engaged in primary production but also those working in activities related to primary agriculture through backward and forward linkages, the increase was even more pronounced.

Figure 24. Global trends in shares of labor in agriculture and agriculture GDP in total GDP

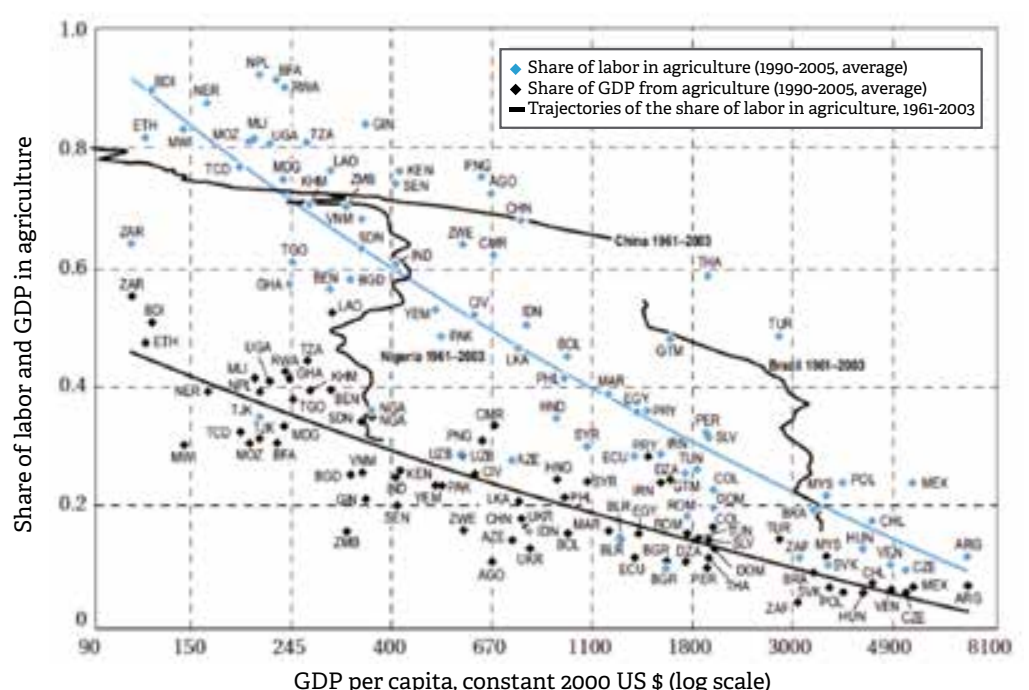

Figure 25. Job creation and destruction in agriculture (1985-2007)

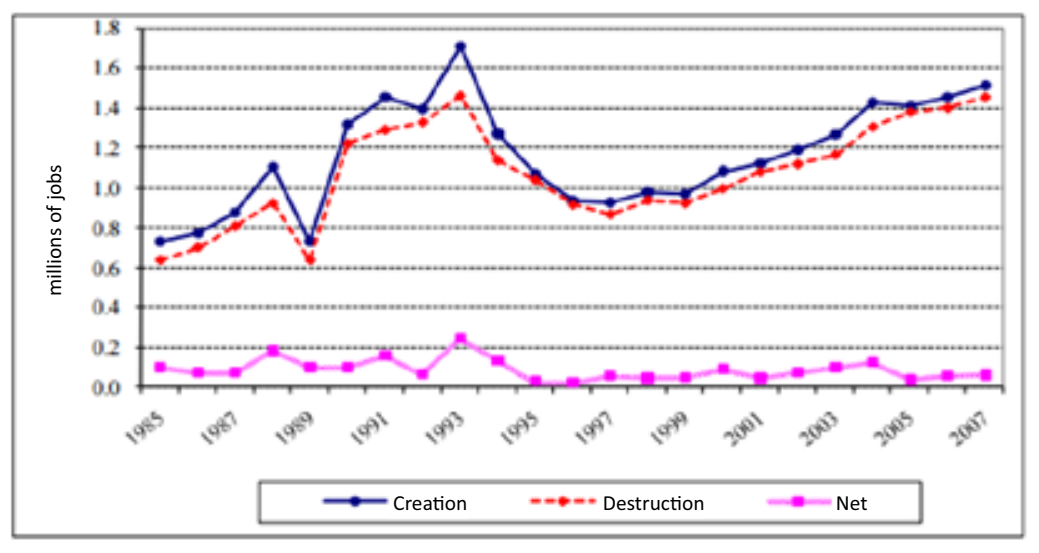


39. Formal employment in Brazil's agribusiness sector has increased in the last decade and today makes up $11 \%$ of total fortimated 34.6 million people share of total formal employment (Figure 26), agriculture has the largest multiplier effect of any sector, so while jobs in primary production have fallen, new jobs have been created at a faster pace along the agriculture value chain (Costa tal. 2013; and Sesso Finho et al., 2011). Furthermore, agriculture is a sector where employment is often informal, often using family labor and informal labor arrangements not captured by formal employment statistics. However, formal agroindustry and agribusiness jobs have become one of the most important sources of employment in many second

Figure 26. Occupational structure in the Brazilian economy
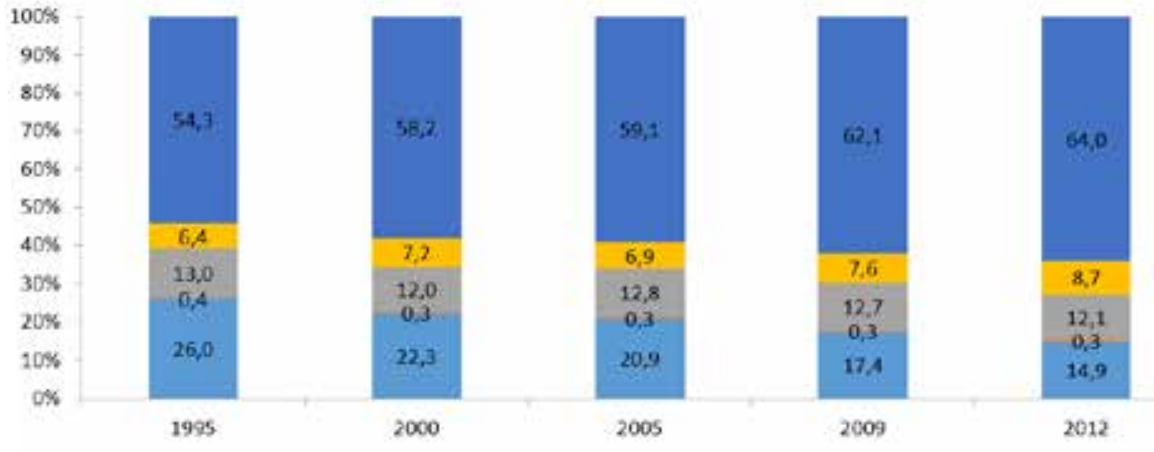

Agriculture Mining Manufacturing Utilities + Construction Services

Table 3. Formal jobs in the Brazilian agribusiness

\begin{tabular}{|l|r|r|c|c|}
\hline States & $\mathbf{2 0 0 6}$ & \multicolumn{1}{|c|}{$\mathbf{2 0 1 2}$} & Var (\%): 2006-2012 & Share 2012 \\
\hline SP & 1.171 .752 & 1.353 .551 & $16 \%$ & $26 \%$ \\
\hline MG & 573.168 & 650.511 & $13 \%$ & $12 \%$ \\
\hline PR & 401.010 & 481.649 & $20 \%$ & $9 \%$ \\
\hline RS & 422.767 & 463.293 & $10 \%$ & $9 \%$ \\
\hline SC & 271.376 & 295.014 & $9 \%$ & $6 \%$ \\
\hline GO & 162.229 & 233.402 & $44 \%$ & $4 \%$ \\
\hline BA & 186.557 & 226.744 & $22 \%$ & $4 \%$ \\
\hline MT & 136.278 & 190.187 & $40 \%$ & $4 \%$ \\
\hline MA & 36.857 & 52.468 & $42 \%$ & $1 \%$ \\
\hline TO & 21.344 & 29.610 & $39 \%$ & $1 \%$ \\
\hline PI & 18.936 & 28.027 & $48 \%$ & $1 \%$ \\
\hline AM & 18.436 & 25.034 & $36 \%$ & $0 \%$ \\
\hline AC & 6.698 & 9.325 & $39 \%$ & $0 \%$ \\
\hline AP & 3.363 & 4.626 & $38 \%$ & $0 \%$ \\
\hline Outros & 1.037 .600 & 1.179 .276 & $14 \%$ & $23 \%$ \\
\hline Brazil & 4.468 .371 & 5.222 .717 & $17 \%$ & $100 \%$ \\
\hline Source: Labor Ministry & \multicolumn{5}{|l}{} \\
\hline \multicolumn{5}{|l}{}
\end{tabular}

40. Brazilian agriculture continues to be dominated by small-scale family farming. Of the 17 million people employed in primary production, about 12.3 million (75\%) work on small farms. As of 2006, small farms in Brazil comprised 84\% large majority of the people who make their living from small farms, especially in the North and Northeast live below the poverty line, and most of their household income is derived from agriculture. One reason is that technical assistance for technology transfer and extension services for small farms is still inadequate. Many public sector technical assistance programs were dismantled in the early 1990s, and only recently have they once again becom a policy priority. According to the 2006 agricultural census data, only $22 \%$ of farms use technical assistance, and assistance. The other half is serviced through cooperatives contracting industries such as with chicken and pig slaughterhouses, and the private sector.

Table 4. Economic activity and land use in Brazil, by size

\begin{tabular}{|l|r|c|c|r|c|}
\hline & \multicolumn{1}{|c|}{ All Farms } & \multicolumn{2}{|c|}{ Small Farms } & \multicolumn{2}{c|}{ Large Farms } \\
\hline & & Quantity & $\begin{array}{c}\text { Share of } \\
\text { Total (\%) }\end{array}$ & Quantity & $\begin{array}{l}\text { Share of } \\
\text { Total (\%) }\end{array}$ \\
\hline Employment (million) & 16.57 & 12.32 & 74.38 & 4.25 & 25.62 \\
\hline Production value (billion BRL) & 146.00 & 42.87 & 29.36 & 103.14 & 70.64 \\
\hline Number of farms (million) & 5.18 & 4.37 & 84.36 & 0.81 & 15.64 \\
\hline Area (million ha) & 333.68 & 80.10 & 24.01 & 253.58 & 75.99 \\
\hline
\end{tabular}

41. When examining employment trends in agriculture and the relationship between labor use and productivity, it policy documents as a prionity for stimulating growth in Brazil but initiatives to improve delivery of education services have fallen short of aspirations. The challenge continues to be the low quality of instruction and the inability to hire new teachers to maintain pace with increases in student enrolment (OECD 2014). Compared to educational standards in OECD and BRICS countries (Figure 27), educational standards in Brazil lag behind, in particular for rural students.

Figure 27. PISA assessment of 15-year old students' performance in mathematics, reading and science (2012) Mean performance scores

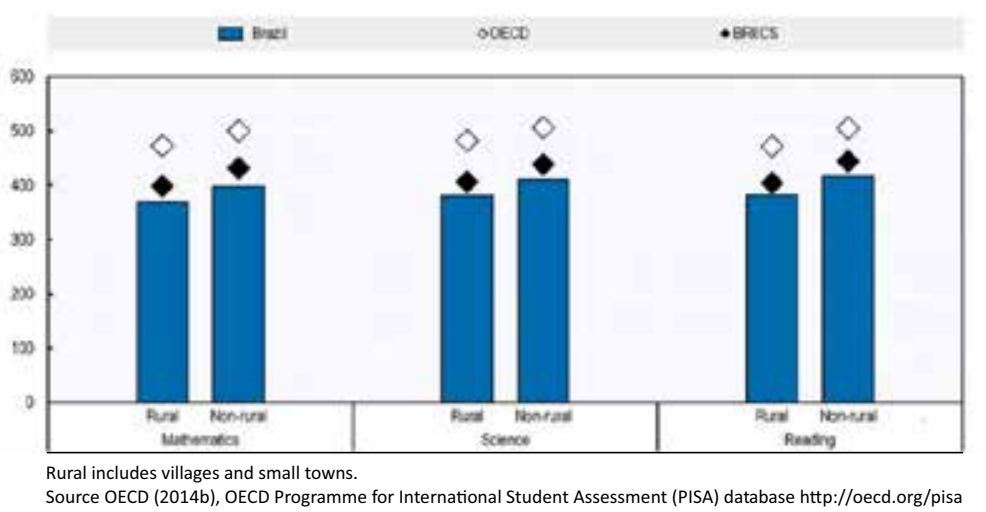

8 Throughout this report, the most recent data available is for 2006 given that it was the last year when an agriculture census was undertaken in Brazli 
42. Productivity of physical capital in Brazil has risen steadily since the 1970s, but the increases have not kept pace with ncreases in the productivity of land and labor. Since 1975, the productivity of physical capital used in agriculture has productivity of land used in agriculture (Figure 28). Possible explanations for the slower growth in productivity of physical capital include the reduced availability and higher cost of credit used for purchasing inputs and equipment. which has the effect of raising the cost of physical capital, as well as the declining efficiency improvements delivered by inputs and equipment.

Figure 28. Agriculture Productivity indexes for Brazil

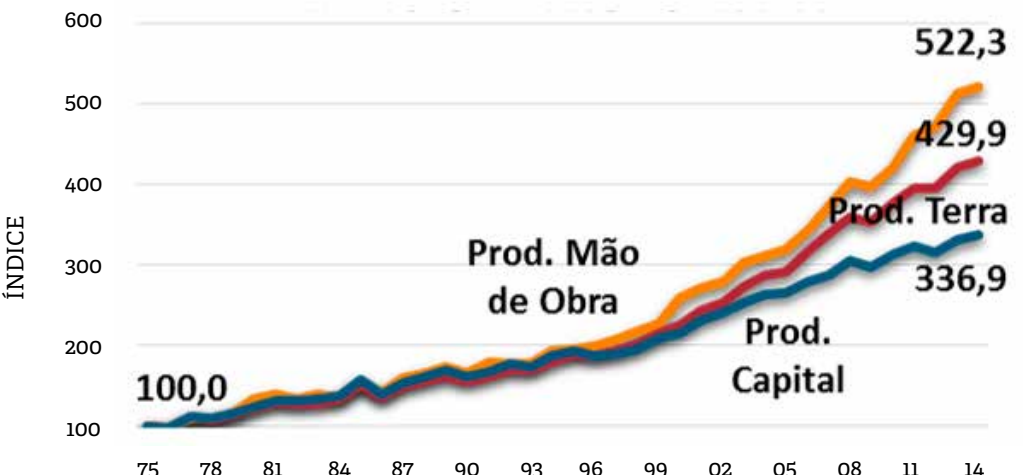

43. Rural credit (credit used by farms and rural households) has increased, but it remains geographically concentrated

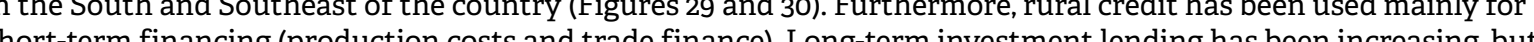
it continues to make up a small share of total rural credit. Access to credit and other agriculture finance tool are key for adoption of new technologies and modern inputs that have an impact on TFP. Without financing, farmers are not able to take advantage of the latest technological innovation and increase productivity to new levels.

Figure 29. Rural credit availability in Brazil

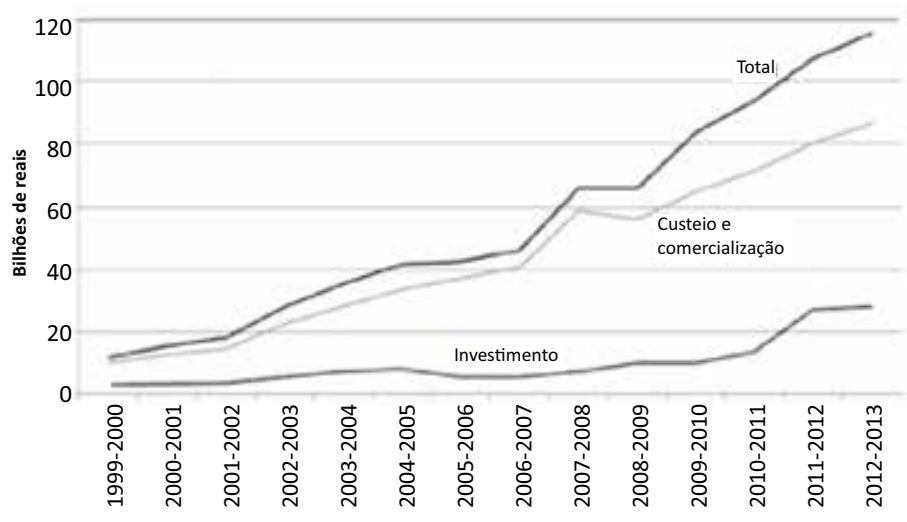

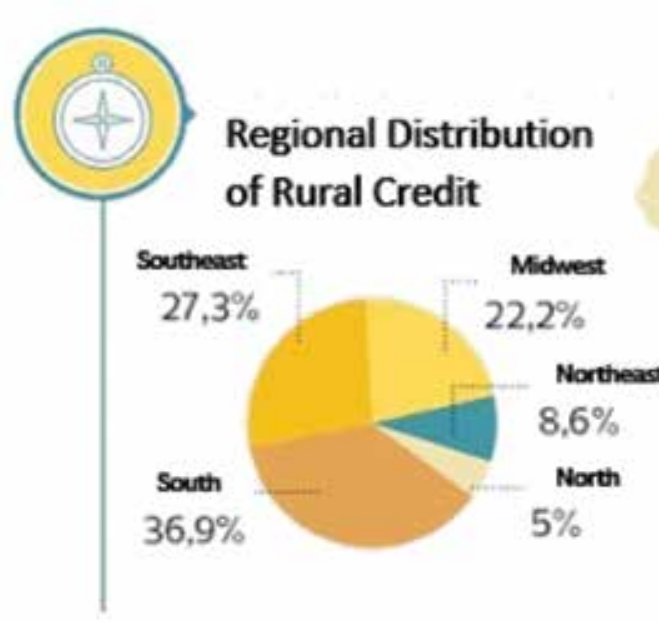

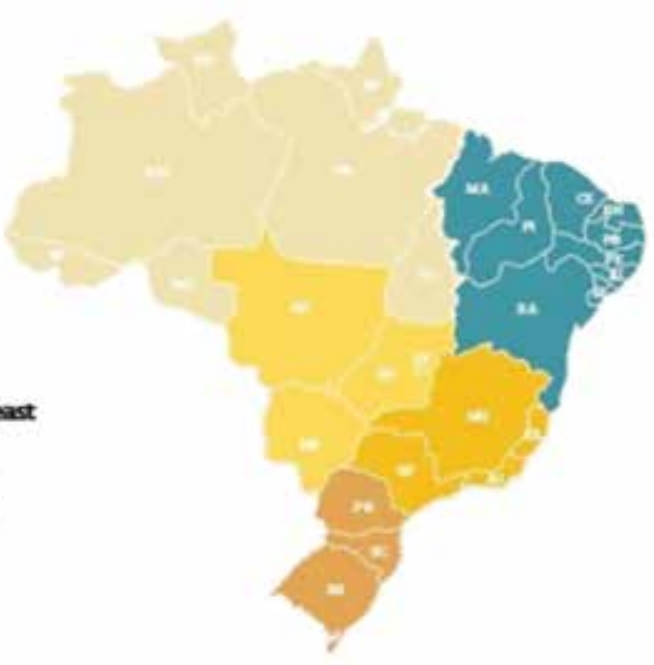

44. More than one-half of all rural credit in Brazil is earmarked for specific sectors. The agriculture sector ranks secon (after the energy sector) in terms of the share of credit going to the sector that is earmarked (Figure 31). Fifty-three
percent (53\%) of rural credit in Brazil is earmarked. Furthermore, measured in terms of subsidies (delivered mainly through controlled interest rates), rural credit is heavily supported. Only credit used in the energy sector and the water and sanitation sector enjoy higher levels of support.

Figure 31. Distribution of earmarked vs. non-earmarked by sector, firms credit, December 2015

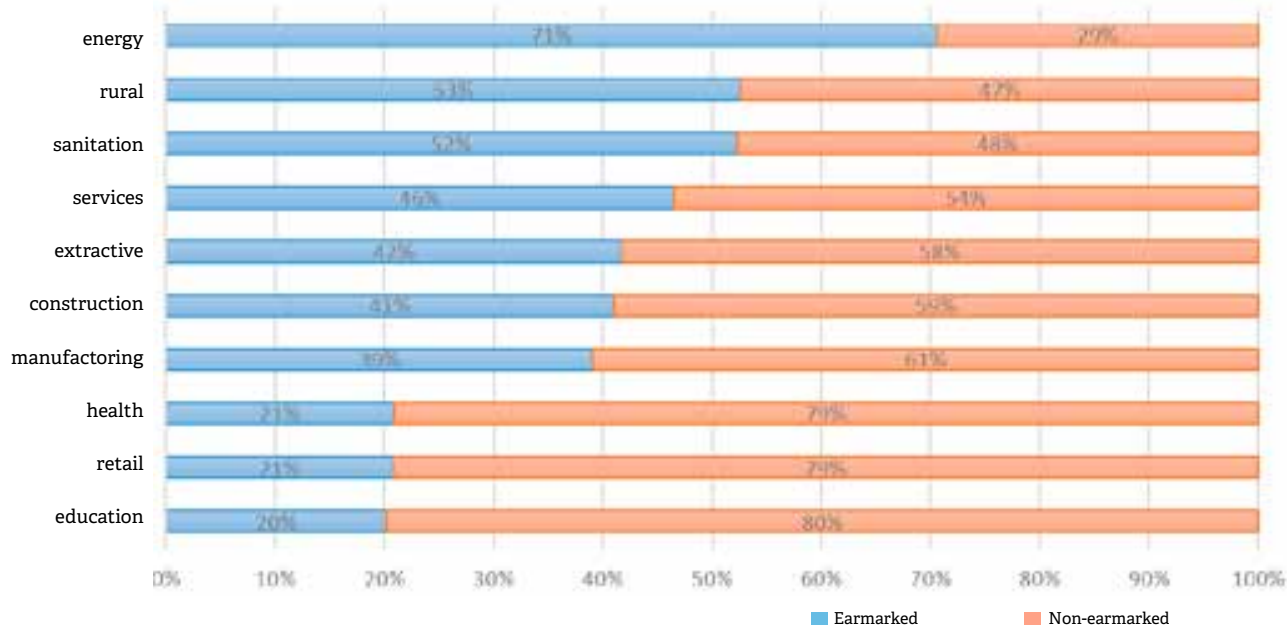



Mexico, and OECD countries. In addition, agriculture insurance coverage is not necessarily linked to rural credit policies and programs, which is a missed opportunity for improving the agriculture credit risk profile of farmers.

46. Inadequate infrastructure is increasingly identified as a major bottleneck to Brazil's agricultural competitiveness. Brazil has inferior overall infrastructure quality relative to almost all its main export competitors (Figure 32). The insufficient investment in infrastructure and agrologistics affects gains in productivity, export performance and domestic market integration. For instance, soybeans make up nearly 11 percent by value of Brazil's total exports. primang to Stanley (2010), Mato Grosso state alone con in ures about 7 pects representing 32 percent of total exports costs for soybean given the long distances that trucks have to travel along poor roads to reach the Santos port (Table 5). Furthermore, the poor roads are particularly vulnerable to weather conditions. In 2016 - a year with record harvests - heavy rains interrupted traffic in the region, causing trucks loaded with soy to be stuck at the point of origin. Some studies indicate that soy transport costs in Brazil can be 7

Figure 32. Global competitiveness index:

infrastructure (1-7 scale, higher indicates greater competitiveness)

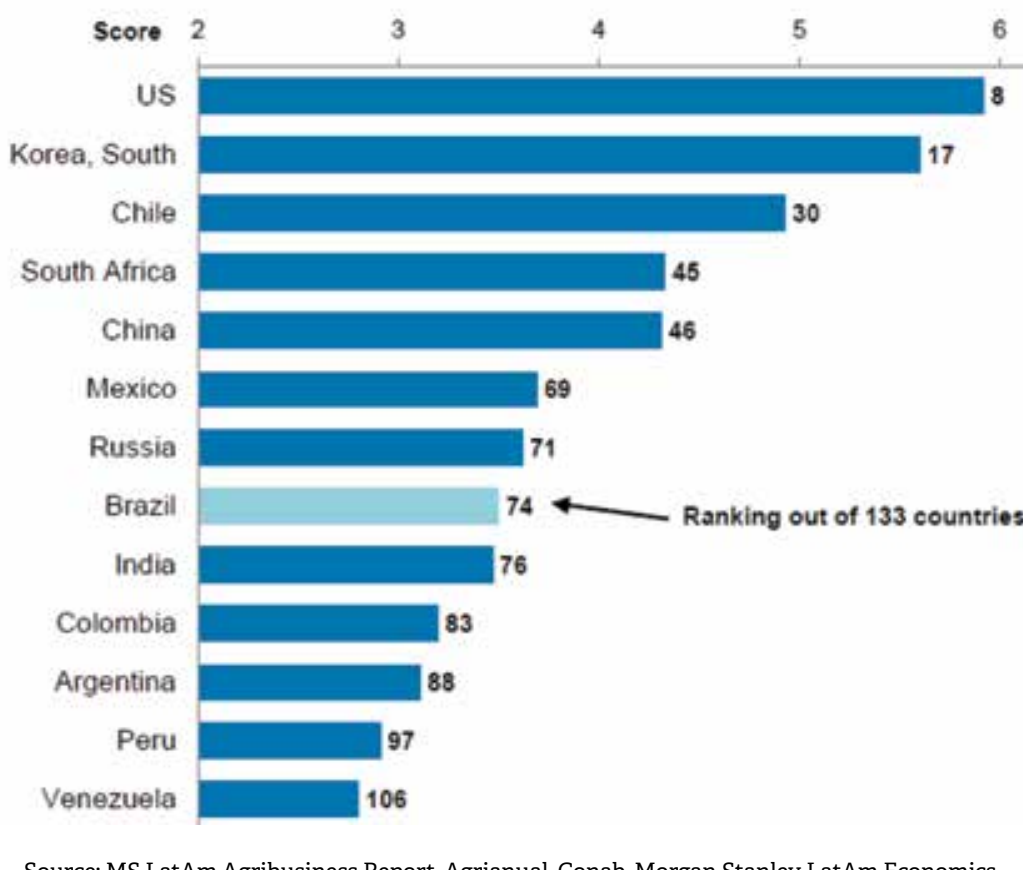

\begin{tabular}{|l|c|c|c|c|c|c|}
\hline & \multicolumn{2}{|c|}{ MT } & \multicolumn{2}{c|}{ MAPITO } & \multicolumn{2}{c|}{ PR } \\
\hline & RS/ton & $\%$ share & Rs/ton & $\%$ share & RS/ton & $\%$ share \\
\hline Total Cost & 601 & $100 \%$ & 576 & $100 \%$ & 515 & $100 \%$ \\
\hline Production cost** & 407 & $68 \%$ & 487 & $85 \%$ & 452 & $88 \%$ \\
\hline Logistic cost** $^{*}$ & 194 & $32 \%$ & 89 & $15 \%$ & 63 & $12 \%$ \\
\hline
\end{tabular}

Includes fertilizers, chemicals, seeds, process, etc

-Includes transportation and ports MT=Mato Grosso; MAPITO=Maranhão, Piaú and Tocantins; PR=Paraná.

Source: MS Lat Am Agrbusiness Report. Agrianual Conab Morgan Stanley LatAm Economics

Source: MS LatAm Agribusiness Report, Agrianual, Conab, Morgan Stanley LatAm Economics 


\section{IS BRAZIL MAXIMIZING AGRICULTURE GROWTH OPPORTUNITIES?}

47. For decades now, agricultural productivity in Brazil has grown much more rapidly than productivity in most
other countries. Since 1970, livestock productivity in Brazil has doubled, and crop productivity in Brazil has quadrupled. These increases in productivity are particularly impressive because they have been achieved even as the deforestation rate has been reduced. While the agricultural productivity frontier in Brazil may not continue to expand at the same rate going forward, if the frontier is to continue advancing in a sustainable manner, there is a
need to start rethinking the agriculture innovation system. Furthermore, average productivity levels in the country could still rise significantly if less productive farms can be assisted to "catch up" to more productive farms.

48. Among the various issues affecting the current performance of agricultural exports is the concentration of the exports on low-processed agrifood products. Of the US\$ 71.46 billion of agricultural products exported by Brazil in
2017 , soybeans accounted for $27 \%$, followed by meat (20\%), sugar $(15 \%)$, coffee ( $8 \%$ ), soybean meal ( $7 \%$ ), corn in grain $(5 \%)$ and others $(18 \%)$. While the relative share of processed products in international agricultural trade tends to remain stable at around $69 \%$, Brazil's export growth comes mainly from primary products. Low processed agrifood products increased by $236 \%$ between 2006 and 2015 , while processed foods increased by only $48 \%$ (Trademap, 2017). Therefore, the diversification of the Brazilian agricultural export agenda emphasizing processed products is the domestic manufacturing and services sectors.

Figure 33. Main imported agriculture products by the world by supplier country (Brazil vs. The rest, 2016) (Trademap, 2017)

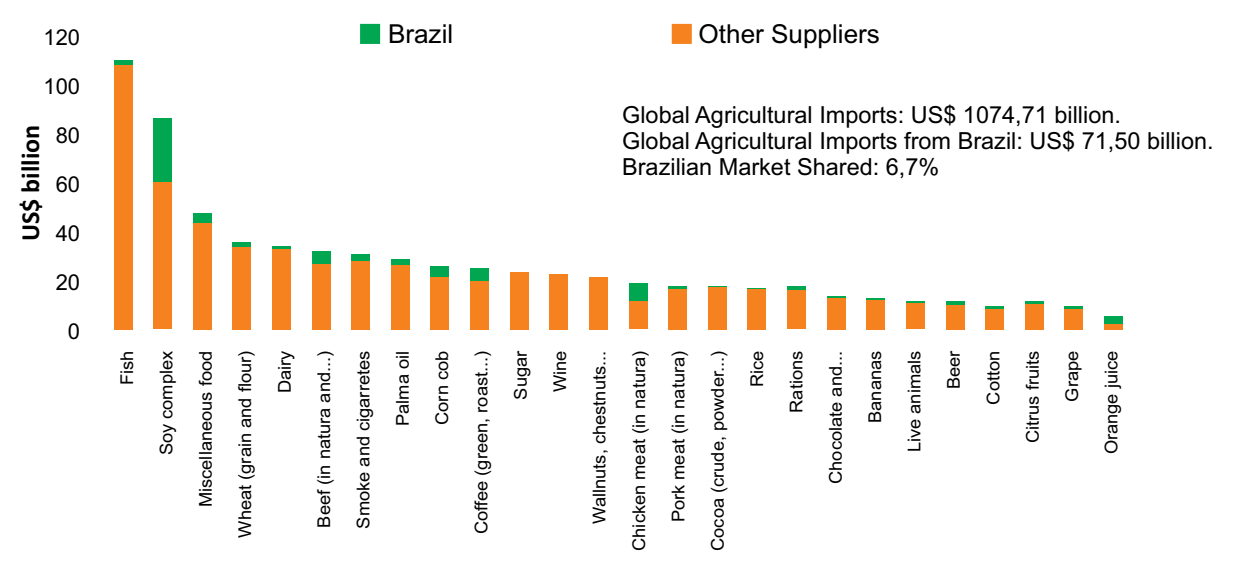

49. Within the family farming sector, a small number of export-oriented commercial family farms have progressed much more rapidly than non-export-oriented family farms. According to Helfand et al. (2015), a small group comprising
around lo percent of all family farms increased its share of total family farm output from around one-half in 1996 to around two-thirds in 2006. The family farms in this group are competitive and dynamic, and they generate sufficient income to ensure a decent standard of living for the family members. In stark contrast to this small group of dynamic family farms, many other family farms (more than one-half of all family farms) generate little or no income
50. Most family farmers in Brazil live in poverty because they have insufficient land and because they produce at extremely low levels of productivity. In the Northeast, more than one-half of family farms operate between zero poverty line. In the South, the share of family farms that are poor is much lower, reflecting differences across regions in access to land and other resources. In the South, only 24 percent of family farms operate between zero and five hectares, and this group achieves higher levels of productivity when compared to the Northeast. Based on farm income alone, 62 percent of this group in the South is poor. One of the main reasons for the differences in the poverty levels of family farmers in the Northeast vs. the South and Southeast is that in the latter regions, family purchasing of inputs and commercialization of output Poverty reduction among family farmers-especially in the Northeast-requires policies that address both insufficient land and low levels of productivity.

51. Low farm productivity in Brazil stems from insufficient levels of physical capital, purchased inputs, and human small farms (both family and non-family) operating only zero to ten hectares have around $\mathrm{R} \$ 50,000$ of on-farm assets. In comparison, in the Northeast farms of the same size in Alagoas and Pernambuco have only 10 to 15 percent of this level of capital. Within regions, there is also ample evidence of differences in the use of capital between

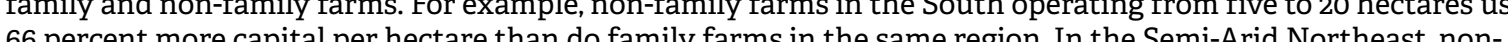
66 percent more capital per hectare than do family farms in the same region. In the Semi-Arid Northeast, nondifferences were observed in the use of purchased inputs within each region.

NATURAL CAPITAL

52. Land degradation in Brazil has been found to be reducing agriculture TFP growth, but investments in natural capital can increase soil quality and boost agriculture productivity. In the Cerrado Region (Center-West), where grains such as soy and maize are produced, the Municipality of Rio Verde, Goias State provides an example where through manmade fertilization and good agricultural practices, an original low-nutrient, high-acidity soil, became fertile soil for intensive crop production. Over an area of 380,000 hectares, an extensive monitoring exercise carried out between levels of nutrients such as phosphorous hav drastically increased (Figure 34) requiring less fertilizer and increasing agriculture productivity after the third and fourth harvest (Figure 35).

Figure 34. Evolution of phosphorous in the soil of agriculture lands in Rio Verde, Goias, Brazil

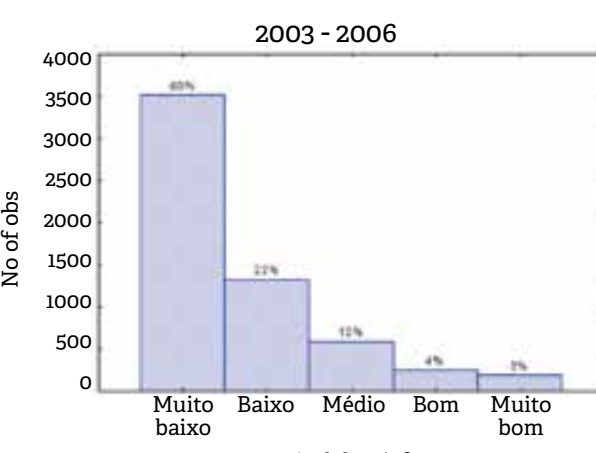

Nivel de Fósfor

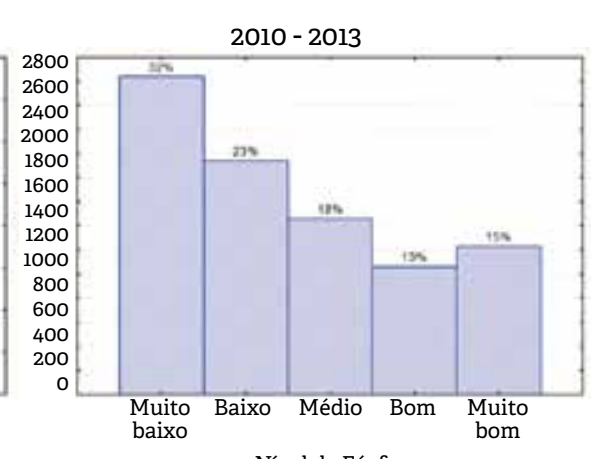


Figure 35. Soy productivity response to phosphorous fertilizer (lands in Rio Verde, Goias, Brazil)
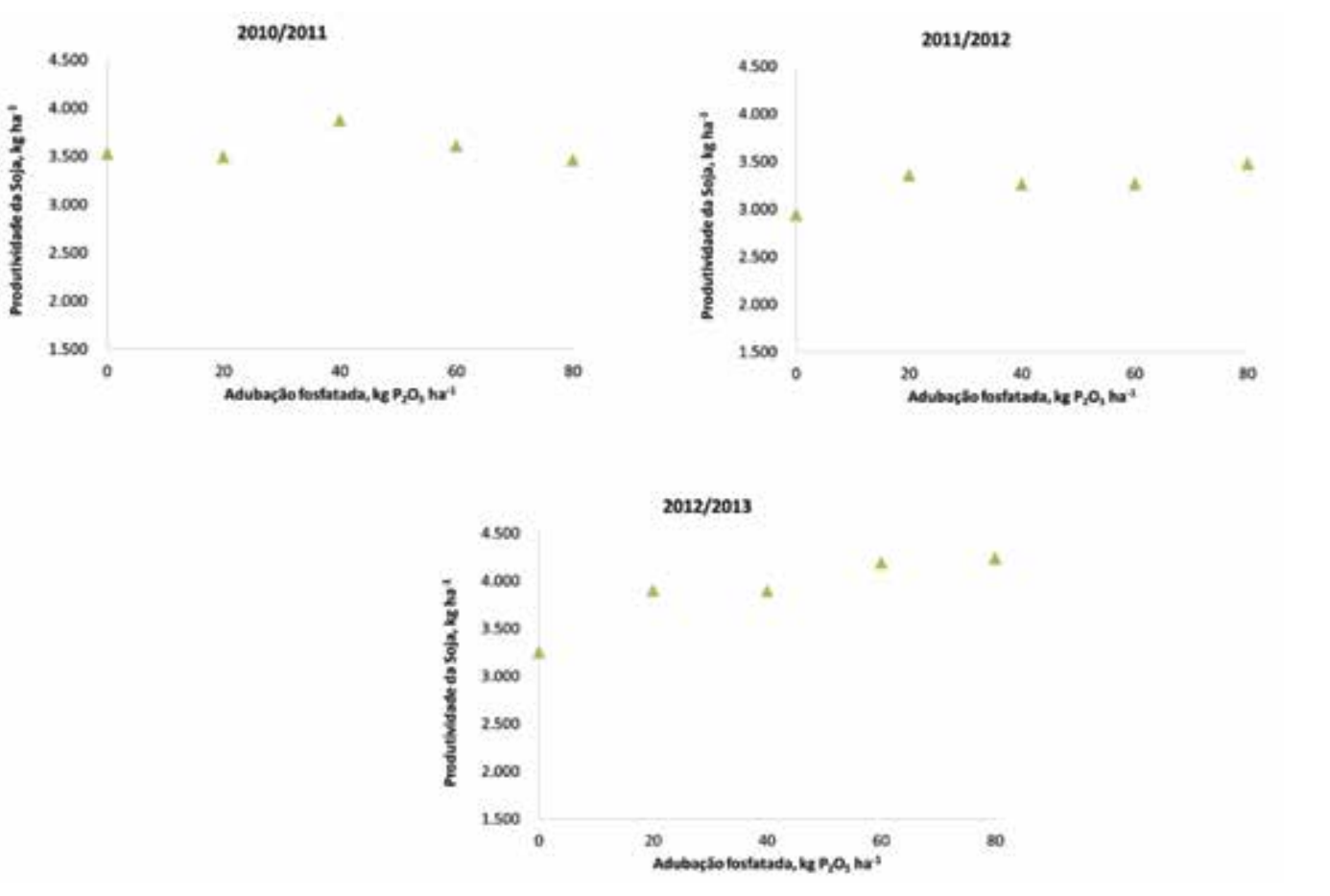

53. Numerous examples of successful initiatives to slow or reverse land degradation make clear that further increases in agriculture productivity can be achieved in Brazil without increasing deforestation and GHG emissions. Most of agriculture land is used for pasture, and most pasture land is degraded, so there is significant potential to boost
productivity by converting pasture land to crop land (Box 2) and/or by migrating from extensive grazing systems to integrated crop-livestock systems - ILPF (see Box 3).

54. The key challenge facing Brazil now is to promote the uptake of technologies that can reduce GHG emission without compromising the productivity and profitability of agriculture, while maintaining low rates of deforestation. Structural causes of deforestation can be eliminated by: (i) increasing livestock productivity, (ii) deforestation, (iv) implementing sustainability-certified forest management practices on designated public londs, and (v) fully implementing key provisions of the 2012 Forest Code, especially the Rural Land Cadaster (CAR). Accelerated implementation of the ABC Program (Box 4) to ensure widespread adoption of zero-tillage cultivation (Box 2) will reduce emissions caused by altering soil carbon stocks. Shifting to more intensive pasture management and meat production systems (Box 3), adopting improved crop varieties, and improving forage for cattle will reduce native forests as required by existing And establishing production forests to provide fuel for the steel industry will allow substitution of non-renewable charcoal by renewable charcoal and contribute to additional emissions reduction and carbon uptake.
HUMAN CAPITAL

55. By global standards. Brazil does not rank near the bottom when it comes to labor productivity, but it has a large agricultural labor productivity is 45 times higher in Brazil than in the least productive country (Table 6). This difference is much larger than the differences observed in other sectors, such as manufacturing, where labor productivity in Brazil is only twice as high as labor productivity in the least productive country. At the same time, agriculture labor productivity in the most productive country is 21.7 times higher than in Brazil. The extent to whi productivity of the global leader is 9 times higher for manufacturing and 4 times higher for mining).

Table 6. Differences in labor productivity between Brazil and other countries

\begin{tabular}{|l|c|c|c|c|c|c|c|c|}
\hline $\begin{array}{l}\text { Economic } \\
\text { Sector }\end{array}$ & \multicolumn{4}{|c|}{$\begin{array}{c}\text { Brazil / the least productive } \\
\text { country }\end{array}$} & \multicolumn{4}{c|}{ The most productive country / } \\
\hline & $\mathbf{1 9 9 5}$ & $\mathbf{2 0 0 0}$ & $\mathbf{2 0 0 5}$ & $\mathbf{2 0 0 9}$ & $\mathbf{1 9 9 5}$ & $\mathbf{2 0 0 0}$ & $\mathbf{2 0 0 5}$ & $\mathbf{2 0 0 9}$ \\
\hline Agriculture & 5,0 & 5,4 & 4,8 & 4,5 & 16,4 & 21,0 & 24,8 & 21,7 \\
\hline Mining & 9,2 & 4,7 & 3,0 & 2,3 & 6,2 & 5,9 & 3,6 & 3,9 \\
\hline Manufacturing & 5,4 & 4,2 & 2,9 & 2,1 & 4,7 & 4,9 & 7,4 & 9,0 \\
\hline Construction & 6,9 & 5,9 & 3,2 & 2,3 & 5,7 & 6,2 & 6,8 & 6,5 \\
\hline Services & 7,9 & 5,7 & 4,0 & 2,9 & 5,6 & 5,9 & 6,5 & 6,4 \\
\hline Total & 8,6 & 6,4 & 4,2 & 3,0 & 6,6 & 6,6 & 7,3 & 7,1 \\
\hline
\end{tabular}

Source: Migueze Moraes (2014)

56. Differences in productivity and income across farms can be attributed to differences in schooling and in the use of capital and purchased inputs. According to Helfand et al. (2015), higher levels of schooling are correlated with is correlated with higher levels of productivity and lower levels of poverty. Farmers who use technical assistance achieve levels of land productivity that - depending on farm size-are about one-third higher in the semi-arid Northeast and about two-thirds higher in the South.

57. Education can play a critical role in helping medium-size farmers move towards the agriculture productivity frontier. According to Vieira Filho e Santos (2011) and OECD (2014), education increases the absorptive capacity of farmers and helps them adopt new practices and technologies; for this reason, lack of education has been a major capital among farmers, and Brigatte and Teixeira (2012) find that between 1980 and 2005 agricultural TFP increased mainly due to education and infrastructure investments (the effect is detected after a significant lag. Investing in new schools has been found to have an impact on the rate of adoption of new technologies by farmers, and relatively low education investments levels in the North, Northeast and Center West have contributed to slow TFP growth in those regions (Alves, 2013). 
PHYSICAL CAPITAL

58. Incentives to invest in physical capital for agriculture production are undermined by a number of factors in (2014), problems with regulatory frameworks in the trade of genetic materials and the sector. High logistics costs and business transactions costs - as documented for example in the World Bank Logistics Performance Rankings ${ }^{9}$ and of Doing Business Surveys ${ }^{10}$ - affect the agriculture sector along with other sectors (Figure 36). Farmers and agribusinesses also must deal with complex and time-consuming bureaucratic processes in attempting to access public services, characterized by constantly changing rules and a lack inter an intra institutional coordination.

Figure 36. Doing Business Ranking and Logistics Performance (2016)

Trading Across Borders (1=best)

Index Customs Rank (1=best)

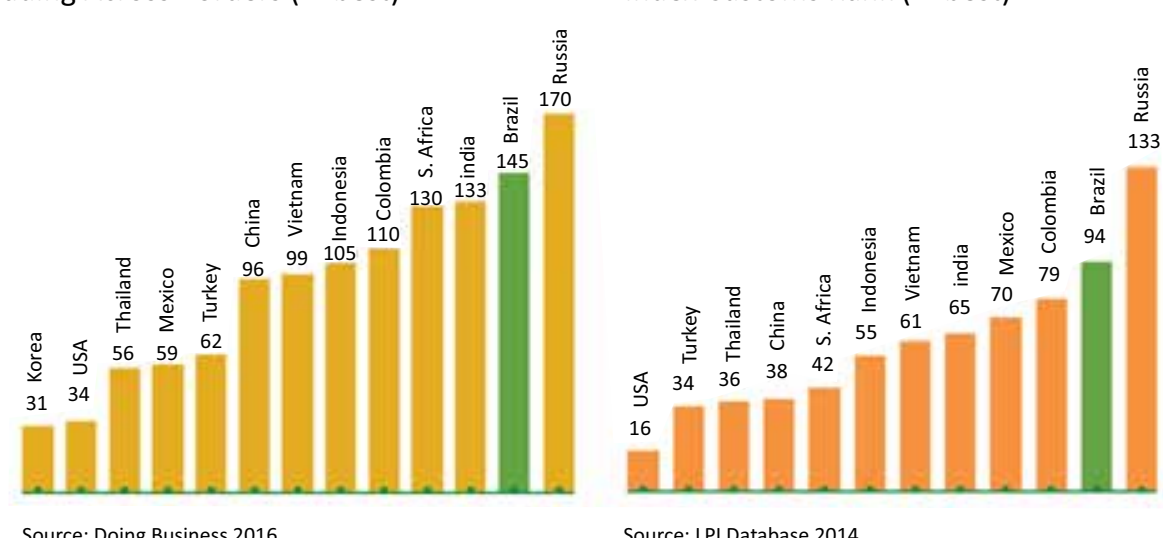

59. Despite the recent reforms that have helped to liberalize trade in agricultural products, border protection of capital and intermediate goods conthues to inflate significantly the cost of agricultural inputs. Tarif protection is high in Brazil for captal and internediate goods, which increases the costs of agricultural inputs and slows the importation agroindustry sectors frequently include local content provisions, making technology development less efficient and potentially more costly.

9 Brazil Logistics Performance Index Ranking is go ( 1 being the best country).

10 Brazil ranks 145 th (out of 189 countries) in the Doing Business 2016 ranking.
Figure 37. Import tariffs for industrial and agriculture goodsi

(2012 or latest available year)

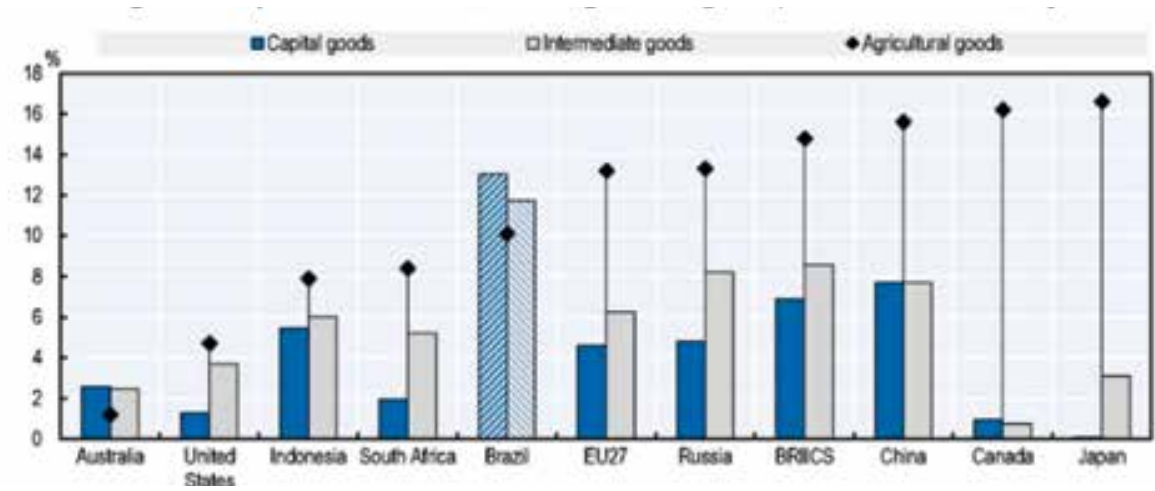

60. Land rental markets in Brazil function poorly, leading to inefficient land use. Rental of land for agricultural use and lessees but instead discouraged landowners from renting out their land. As a result the share of argicultural land that is rented declined from around 10\% in 1940 to only 2.4\% in 2006 (Figure 38). Today the land rental market in Brazil is slightly smaller than the average land rental markets throughout the Latin America region, and it is much smaller than the land rental market in USA and Europe $6.2 \%$ of total land being rented in Brazll in 2000 vs. 37.7\% in USA) (Figure 39). The lack of a vibrant land rental market in Brazil has important implications in terms of is being rented.

Figure 38. Leased or sharecropped land area in Brazi

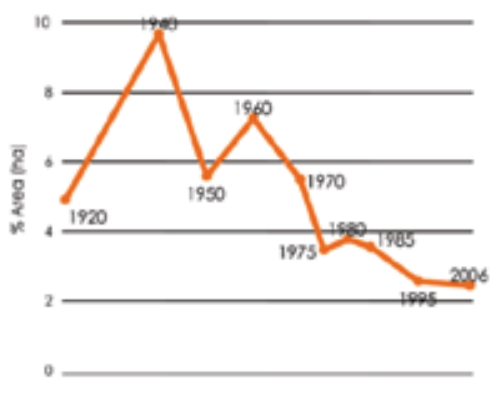

source: 2006 Census of aricullure - IBSE 


\section{CONCLUSIONS AND POLICY RECOMMENDATIONS}

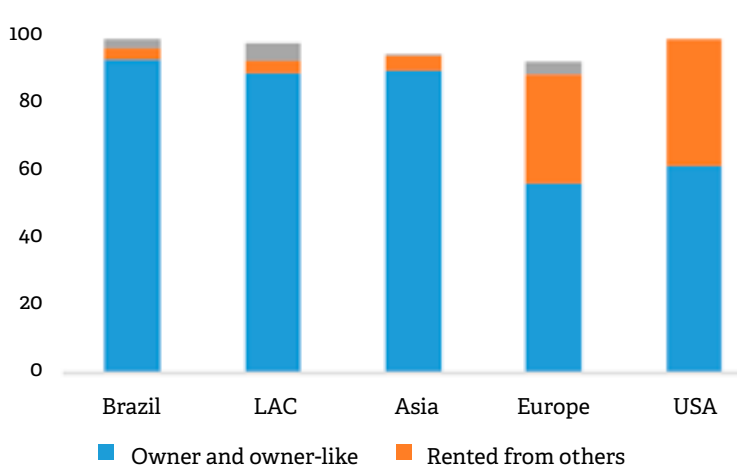

Under other forms

Figure 40. Sugarcane productivity vs. output under leasing or sharecropping

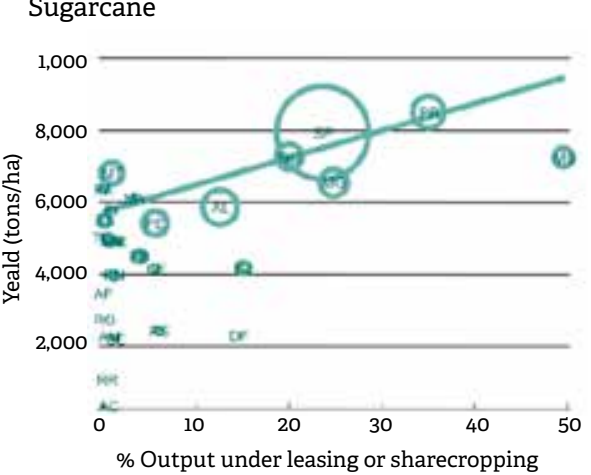

61. Capital markets are failing to provide adequate resources for long-term agriculture development in Brazil, and the

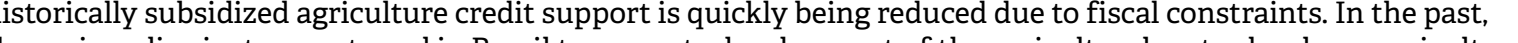
credit programs which not coincidentally represent the largest agriculture public expenditure item Agriculture credit programs have served as vehicles for distributing public resources, but the impact of these resources has often been less than expected, as many programs have lacked clear development objectives (with some public program exceptions), and most have been poorly targeted (larger farmers and firms have captured the lion's share of earmarked credil). In the past, most agricultural credit was heavily subsidized, imposing a high cost to the government, but recently the gap between market rates and earnar.

62. Brazil harbors large opportunities to increase agrifood power and competitiveness in international markets by investing in adequate and better quality infrastructure and improve the management and maintenance of existing invest agro-logistic business.
63. The growth in Brazilian agriculture TFP has been impressive in the last decades, and this positive experience can While productivity in the manufacturing and service sectors grew by $-5.5 \%$ and $11.7 \%$ respectively between $2000-2013$, agriculture productivity grew by 105.7\%. The significant growt in agriculture productivity was driven mainly by two sets of public policies that benefited the agriculture sector difficulties in accessing international markets and technologies the agriculture sector of Brazil was able to lar from internal $R \& D$, while being increasingly connected to international markets and foreign agriculture technologies and inputs.

64. Increasing domestic and global demand for agricultural commodities, coupled with the imperative to address cimate change, highlight the urgent need to reassess Brazil's agricultural development strategy Considering that the size of each sector of the economy reveals its influence on the aggregate growth of productivity over a period of time, the growth of the agricultural sector over the last decades is clearly not producing the expected spillovers from a traditional structural transformation for other sectors of the economy (with the exception of agroindustries. consequently, if such spillovers are not created, the own growth of the agriculture sector could be hampered. This Brazil needs to review deeply the barriers to productivity growth in all sectors of its economy in an integrated way and a not only from a sectorial perspective.

65. Agriculture policy reforms are needed to ensure that the sector can continue to drive growth, generate jobs, and increase the incomes of rurat house holds while safeguarding the sustainable use of the natural capital which agriculture depends. Taking into account the policies and programs that have supported the impressive development to date of Brazil's agriculture sector, the challenges and opportunities faced by the sector going forward, and the current fiscal constrained scenario, this report concludes by presenting a series of policy drivers for guiding future interventions to maximize agriculture productivity, while having positive social (poverty reduction in an environmentally sustainable way: (ii) closing the agriculture productivity gaps for those who have been left behind; and (iii) exploiting opportunities for agricultural productivity growth to generate more and better jobs. All three policy drivers can contribute to poverty reduction.

66. Promoting agriculture productivity growth and improving ecosystem protection are not mutually exclusive. Experience shows that it is possible to change land use patterns in a way that achieves both natural protection and in Mato Grosso do Sul beginning in the 200os, and expansion of integrated livestock-forestry-crop systems beginnin in 2004 provide clear evidence that agricultural productivity can be increased while critical ecosystems are being emissions by conerting degraded pastureland to sustainably managed intensive farming systems Over 40 million hectares of degraded pastureland located outside the Amazon region are suitable for producing sugarcane, an area equivalent to more than $65 \%$ of total Brazilian cropland. Converting this land to sugarcane production would boost the value of agricultural production and lower greenhouse gas emissions. Achieving these results will require more effective dissemination of int

67. Agricultural development driven by productivity growth provides a potential pathway out of poverty for and ins of Brazllans. Where farmers have sufficient land, poverty reduction depends on increasing productivity two to three times the profit per family member of farms of the same size that did not do so. As a result poverty 
was significantly lower for these farms. In both South and Northeast regions, technical assistance was more strongly associated with gains in land productivity and income than was credit. This suggests that while credit for technology transfer and increase productivity can have a direct impact on poverty reduction of family farms.

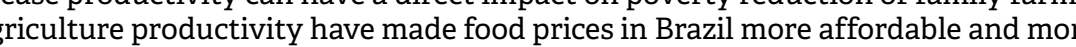
stable, in particular for the low-income urban population.

68. Agricultural development provides a potential pathway out of poverty for the rural poor, but there are others.

The pathways out of poverty for the rural poor include:
(i) agriculture-either through intensification of family farms or wage labor; (ii) non-agriculture-either through
abor market earnings or self-employment: (iii) migration for those households that choose to exit from the sector and (iv) transters for those households without the potential to to henseholds that choose to exit from the sector that there are num successful transitions (see for example World Bank 2003. World Bank 2008, and Helfand and Pereira 2012).

ADVANCING THE AGRICULTURE PRODUCTIVITY FRONTIER IN A SUSTAINABLE WAY

69. Technological change leading to sustainable high TFP growth will require reforms to the national agriculture innovation system. TFP growth in Brazil has been driven by technical change among a relatively small number of efficient producers. Accelerating that growth and sustaining it will require reaching the majority of producers who
have unable to match the productivity gains of the most efficient producers (see below). Agriculture innovation being composed of agriculture research, extension and education, there is a need to improve and reform all three to achieve further technological change in agriculture. The agriculture innovation system of Brazil is mainly composed of private sector enterprises and public sector institutions such as: Embrapa, state-level agriculture research and

70. Revitalizing the national agriculture innovation system will require a clarification of roles and improved coordination among key actors. Three features of the current innovation system are undermining the effectiveness of the system by discouraging collaboration, leading to duplication of effort, and creating conflicts of interest. Firs,
state-level agriculture research and extension agencies are going through a restructuring process, and it is still unclear how applied research and agriculture extension services will be adapted to state-level specific situations. The National Agency for Technical Assistance and Rural Extension (ANATER) created in 2013 can address such heterogeneity and ensure the efficient and effective us of public sector investments in technology transfer by transfer and extension activities, which often results in the diversion of resources away from the former in favor of transfer and extension activities, which often results in the diversion of resources away from the former in favor of in terms of coordinating and delegating functions to other institutions such as universities, state-level organizations, and private firms. This last issue is also compounded by the limitations that Embrapa has in terms of intellectual

property (IP) and sharing patents on genetic material with private partners (implementation of the Cultivar
Protection Law and the Industrial Property Law ${ }^{1}$ ).

II There is a proposal being discussed in the Brazilian National Congress to create a subsidiary of Embrapa (Embrapatec) that would be able to trade new technologies and assets in the market, giving the public sector's agriculture R\&D institutions more flexibility and dynamism to engage with the private sector in PPP opportunities.
71. Agriculture innovation in Brazil merits a larger share of public spending on agriculture and on public-private artnerships (PPPs). Without increasing the overall agriculture public expenditures, a reallocation of agricultur Furthermore, there is a clear deficiency in coordination on agriculture innovation between public sector institution such as Embrapa and the private sector. In the past, Embrapa has developed several projects and technical cooperation agreements with private institutions, NGOs, and Universities's, but this is often done in an ad-hoc, cas by case basis. Furthermore, the OECD (2014) has pointed out that Brazilian legislation makes it difficult for public organizations to enter into relationships and contracts with the private sector. The main constraint is that under
Brazilian law, public resources need to benefit society. Therefore, research conducted with public funding cannot benefit particular firms or individuals, making it difficult public-private to secure approval for many PPPs (Contini and Andrade, 2014).

72. Agricultural trade policies should be pursued as a way of attracting foreign investment and know-how that can drive productivity growth needed for Brazil to remain competitive in global markets (World Bank, 2015). Agriculture productivity growth will continue to depend on Brazil's capacity to expand its agroexports. Increases in agroexports have a direct positive impact on agriculture TFP in Brazil through incent

73. Land rental markets must be deregulated to reflect current realities. Land rental markets need to be further
developed in Brazil to ensure an efficient land use. Current regulations are clearly outdated. Land rental market developed in Brazil to ensure an efficient land use. Current regulations are clearly outdated. Land rental market improvements have been found to have a direct impact on agriculture productivity by allowing proo

74. Brazil should move towards a market-based agriculture credit system. This public policy direction is crucial for encouraging competition among financial institutions and reducing the dependency of credit programs on public resources. Agriculture credit in Brazil tends to be costly and difficult to access, in particular long-term credit, which is scarce and concentrated on one public bank, BNDES. Short-term agriculture credit by public and private banks is nonexistent), with a high cost for Brazilian society in general.

75. Public policy should address agrologistic deficiencies and the risks they pose to the sector. Such limitations are an important barrier to agriculture productivity growth, in particular in lagging regions. More specifically, increase
investments in infrastructure improvements in terms of quality and quantity in the mainly on rural roads sections connecting with major highways. Such investments would increase transport productivity, in addition to reduce the costs associated with the transport operation for producers and along the supply chain. Also, incentives and policies to encourage the expansion of storage capacity within the farm level and strategic locations. The beneits would commercialization and logistics strategy-

76. Agriculture policies in Brazil, which already include environmental considerations, can be made more flexible to respond to emerging trends. Brazil has made impressive progress in mainstreaming environmental considerations
within agriculture policies and programs. Recent examples include the introduction of the CAR, the enactment of requirements for maintaining forest reserves within farms, and the promotion of CSA through the ABC program (Box 4). Reforms are needed, however, to ensure that they can respond quickly to emerging issues. For example, consider the case of deforestation. In the Amazon region, deforestation has been driven by cutting down forests in small increments (less than 25 ha) (Figure 41), but outside the Amazon region deforestation continues to take place circumstances in recogntion that the underlying dynamics are often location-specific Effective m mo roringal enforcement to reduce deforestation must be done in all five biomes particularly the Cerrado and enforcement of environmental regulations must take place in rural properties, as these private lands are home to one-third of all 
Figure 41. Amazon deforestation: relative participation by polygon size

$$
\text { (2002-2011) }
$$

$$
\begin{array}{r}
\text { Annual } \\
\text { Deforestation } \\
3
\end{array}
$$

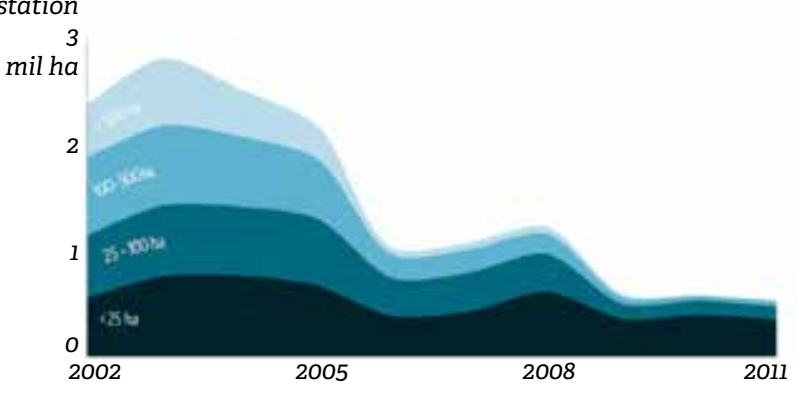

Note: The figure shows the relative participation of each polygon size category in total annual
Amazon deforestation A Adeforestation polygon is acontiguous deforested area as captured in Amazon deforestation. A deforestation polygon is a contiguous deforested area, as captured in
satellite imagery. The sample is composed of the Amazon biome. Data source: INPE (2013).

Figure 42. Accumulated deforestation and remaining native vegetation in Brazilian biomes

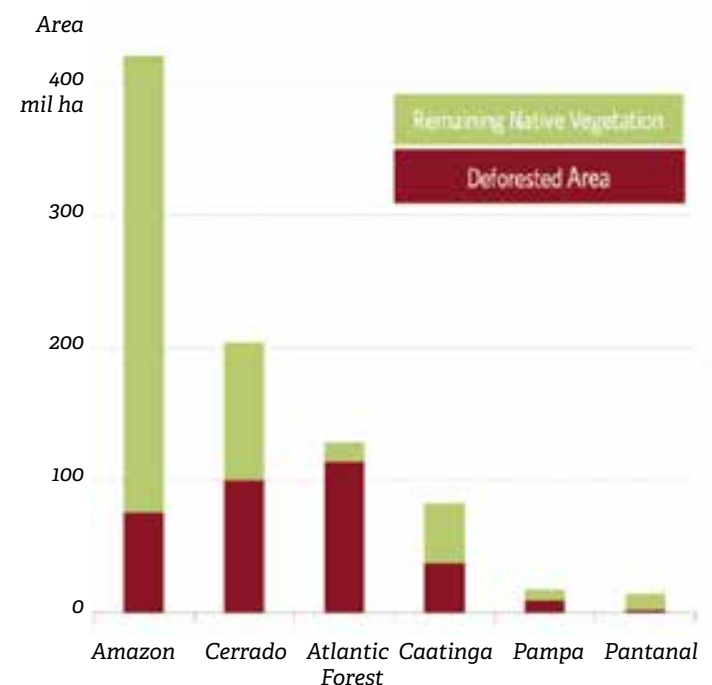

CLOSING THE AGRICULTURE PRODUCTIVITY GAP FOR THOSE LEFT BEHIND

77. In addition to pushing out the agriculture productivity frontier, efforts are needed to help those who have been teft behind catch up. This will mean focusing on regions and farm size categorles in which TFP growth has been slowest TFP growth rate was experienced by farms in the $20-100$ ha size class (1.14\% per year), followed by farms in the $100-500$ ha size class $(1.29 \%$ per year). This pattern has varied somewhat by region. In the Northeast, Southeast, and South, the slowest TFP growth has occurred among farms in the 100-500 ha size class. In the North, TFP growt has lagged among the largest farms, and in the Center-West among the smallest. It is likely that TFP growth has lagged in the 100-50o ha size class because farms in this class-considered medium size in Brazil-face numerous adopting improved production technologies at the same rate as farms in other wize classes.

78. Agriculture extension and rural education can make important contributions when it comes to helping lagging arrese share of Brazilian producers. Scope exists to improve agricultural extension and eduction, both in terms of increasing the level and quality of education of farmers to leave them better equipped to adopt innovations, and in terms of improving extension services to increase the number of farms reached, the frequency of interactions, and the overall quality of the services.

79. Improving connectivity will be critical as well in helping lagging farmers catch up. An important factor explaining lagging productivity growth in some regions and among certain farm size classes is lack of connectivity to markets. Many Brazilian producers face transport bottlenecks and incur high costs due to inadequate public infrastructure investment in transportation infrastructure. Investments are needed in roads, rail networks, river transport improve competitiveness of farmers seeking to expand their presence in markets. Because private firms have little incentive to make infrastructure investments, scaled up public investment will be critical.

80. Research is needed to identify the unique obstacles facing lagging farms, to inform the design of policies that help them improve their needed is in the barriers to credit. Specific difficulties faced by mid-size farmers in attempting to access rural credit include: (i) non-availability of technical assistance required by banks; (ii) difficulty of complying with environmenta laws; (iii) difficulty of meeting land tenure requirements; (iv) high cost of assembling required legal and accounting Additional barriers faced by farmers attempting to access rural credit that is conditional on the adoption of sustainable agriculture practices such as the ABC Program include; (i) lack of knowledge about CSA technologies and practices; (ii) lack of preparedness of rural credit officers to explain the benefits of such credit lines; (iii) lack of access to technical assistance; (iv) non-competitiveness of credit lines linked to adoption of sustainable practices compared to regular commercial credit lines; and (v) lack of credit for medium- to long-term investments (Lopes and

EXPLOITING OPPORTUNITIES TO GENERATE MORE AND BETTER JOBS

81. Agricultural productivity growth can open new employment opportunities in on-farm jobs. Evidence is ccumulating from around the world showing that agricultural productivity growth can be a powerful engine of job creation. This seems counter-intuitive, because agricultural productivity growth is often achieved by expanding conversion of extensive systems to intensive systems, the overall demand for labor increases. Instead of agriculture 
workers migrating to cities to find employment in the industrial and service sectors, agriculture productivity growth creates more stable jobs (year-round) by farmers adopting a second-harvest for grains such as maize (milh fruits and vegetables. In Brazil, even though the share of formal agriculture jobs as percentage of total jobs has fallen with the adoption of labor saving technologies, primary agriculture is a net job creator (job creation has been outpacing job destruction).

82. When agricultural productivity growth is accompanied by significant increases in the volume and value of production, significant new jobs are created in the agribusiness and agroindustry sectors. By increasing volumes and value added, jobs have been created through backward and forward linkages in the industries that supply inputs to the agricultural sector and in the industries that transport, store, process, and distribute agricultural commodities. Jobs in the agribusiness sectors have been increasing at a particularly robust pace, to the extent that the sector Brazil where the area cultivated with soybeans expanded experienced an increase in agricultural output per worker a reduction in labor intensity in agriculture and an expansion in industrial employment. These correlations are consistent with the theoretical prediction that the adoption of labor saving agricultural technologies induces the reallocation of workers towards the industrial sector. However, causality could run in the opposite direction. For example. an increase in labor demandin the crops, like soy.

83. It is important to seek better alignment and complementarity between social protection programs and formalization of rural jobs. The Bolsa Família program provides a good example of the cost of lack of coordination - the way formalize their jobs in agricultural enterprise; at the same time, employers are reluctant to hire informally because this exposes them to the possibility of large fines under the prevailing severe labor laws.

84. Investments to promote youth inclusion in rural non-farm jobs in dynamic agricultural areas will likely be more effective than similar investments in a stagnant agricultural area. In land abundant countries, improving land rental effective than similar investments in a stagnant agricultural area. In land abundant countries,
markets can provide an avenue for greater rural youth engagement in agricultural production.

\section{REFERENCES}

Alves, E. Excluídos da modernização da agricultura - responsabilidade da extensão rural? Revista de Política Assunção, J., Bragança, A.., \& Hemsley,
ers and Potential Solutions. CPI Report.

Assuncao, J. and Chivari, J. Towards Efficient Land Use in Brazil. New Climate Economy Project. 2015. Assunção, J., \& Pietracci, B. (2014). What Happens When Sugarcane Comes to Town? Evidence from Brazil. Working

Paper.

Assunção, J., Gandour, C., Hemsley, P., Rocha, R., \& Szerman, D. (2013). Production and protection: a first look at key hallenges in Brazil. Climate Policy Initiative. Climate Policy Initiative.

Barioni, L.G.; Lima, M.A.; Zen, S.; Guimaraes Junior, R.; Ferreira, A.C. A baseline projection of methane emission

by the Brazilian beef sector: preliminary results. In: Greenhoij,
Proceedings. Christchurch, New Zealand, 2007. p. xxxii-xxxiii.

tecnológica do setor agropecuário na economia Brasileira, 2001. Braślia: Embrapa, 2002. p.147-202.

Benites, Vinicius; and Ribeiro, Jose Eustaquio. Acumulação de Capital na Fertilidade dos Solos Brasileiros.

Background Paper. June, 2017.

Brigatte, H. and Teixeira, E.C. Determinantes de longo prazo do produto e da produtividade total dos fatores da agropecuária brasileira no período 1974- 2005. Revista de Economia e Sociologia Rural, Piracicaba, SP, v. 49, n. 04, p. 815-836, ./dez. 2011. Impressa em janeiro de 2012

Bustos, P., Caprettini, B. and Ponticelli, J., 2016. Agricultural productivity and structural transformation: Evidence
frazil The American Economic Review, 106(G). phe

Contini, E. and R.P. Andrade. Experiência da Embrapa em parcerias público-privadas.". Ciencia e da Tecnologia para to do Agronegócio, Vicosa: Universidade Federal de Vicosa. Suprema Gráfica Editora, 2014.

RESR, 2013

Freitas, Rogerio E. (Chapter 12) in De Negri, F. e Cavalcante. L.R.M.T. Produtividade no Brasil: desempenho e

terminantes. 2014.

Euglie, K.O; Wang, S.L.; Ball, E. Productivity growth in agriculture: an international perspective. USA: USDA, 2012. Garcia-Escribano, M., Góes, C. and Karpowicz, I., 2015. Filling the Gap: Infrastructure Investment in Brazil.

Economics, 107, pp.38-48. Helfand, Steven M., Moreira, Ajax, and Bresnyan, Edward J.
ing Opportunities and Closing Gaps. World Bank. June 2015 .

Helfand, Steven M., Magalhaes, Marcelo, and Rada, Nicholas. Brazil's Agricultural Total Factor Productivity

Growth by Farm Size. Inter American Development Bank. September 2015.

Garcia, Junior R. "O Papel das Importaçôes nos Ganhos de Produtividade na Agricultura Brasileira." Background per. June, 2017.

Gasques, J. G;; Bacchi, M. R. P; Rodrigues, L.; Bastos, E. T; Valdes, C. Produtividade da agricultura brasileira: hipótese da desaceleração. In. Vieira Filho, J. E. R.; Gasques, J. G.; Carvalho, A. X. Y. (Orgs.) Agricultura, transformação produtiva e

Gasques, J. G.; Bastos, E. T.; Bacchi, M. R. P. Capítulo 11: produtividade e fontes do crescimento da agricultura
brasileira. In: De Negri, J. A.; Kubota, L. C. (Orgs.). Políticas de incentivo à inovação tecnológica no Brasil. Ipea, 2008 . Gasques, J. G.; Bastos, E. T.; Bacchi, M. R. P.; Valdes, C. Capítulo 1- Produtividade Total dos Fatores e transformaçōes
da agricultura brasileira: análise dos dados dos Censos Agropecuários. In: Gasques, J. G.; Vieira Filho, J. E. R.; Navarro, Z. 
(orgs.). A agricultura brasileira: desempenho, desafios e perspectivas. Ipea, Brasília-DF, 2010.

Gasques, J. G.; Bastos, E. T;: Contini, E.; Saab, A. A.; Silva, L. F. da. Projeções do agronegócio mundial e do Brasil. In: Anais da XLV Congresso da Sociedade Brasileira de Economia, Administração e Sociologia Rural (Sober), de 22 a 25 de julho

políticas. Revista de Política Agrícola, ano XXI, nº 3, jul/ago/set 2012 Gasques, J. G.; Bastos, E. T.; Valdes, C.; Bacchi, M. R. P. Produtividade da agricultura: resultados para o Brasil e

estados selecionados. Revista de Política Agrícola, ano XXIII, n 3, jul/ago/set 2014 .

Gã Gasques, J. G.; Bastos, E. T.; Valdes, C;; Bacchi, M. R. P. Produtividade da agricultura: resultados para o Brasil e o caso de 27 a 30 de julho de 2014 , Goiânia, Goiás.

Gasques J G. Con Goiño J C P. R. da Crescimento produtividade da agricultura brasilera Texto para disussấ 2. Instituto de Pesquisa Econômica e Aplicada (Ipea), 1997.

Gasques, J. G.; Conceição, J. C. P. R. Transform eão estruturais da agricultura e produtividade total dos fatores.

Texto para Discussão no 768 , Instituto de Pesquisa Econômica e Aplicada - Ipea, Brasília-DF, 2000.

Gasques, J. G.; Rezende, G. C. de.; Villa Verde, C. M.; Salermo; M. S.; Conceição, J. C. P. R. da; Carvalho, J. C. de S.

Desempenho e crescimento do agronegócio no Brasil. Texto para discussão no 1.o09, Instituto de Pesquisa Econômica e

Aplicada (Ipea), 2004.

Gasques, Jose G. “A Produtividade Total dos Fatores da Agricultura ajustada pela Degradação de Terras."

Lema, Daniel. "Crecimiento y Productividad Total de Factores en la Agricultura Argentina y Países del Cono Sur 1-2013". World Bank Working Paper. 2015

Lopes, Desiree and Lowery Sarah. Credito Rural no Brasil: Desafios e oportunidades para a promocao da Miguez e Moraes (Chapter 7) in De Negri, F. e Cavalcante. L.R.M.T. Produtividade no Brasil: desempenho minantes. 2014.

Sesso Filho et al. Geração de Renda, emprego e impostos no agronegócio dos estados da região sul e restante do

Basil. Economia \& Tecnologia - Ano 07, Vol 25 - Abril/Junho de 2011.

Silva, D. B. L. da. O impacto da abertura comercial sobre a produtividade da ing rgas, 2004. Available at: <https.//goo.gl/aKSwHm?

.

C. T.M.T. Produtividade no Brasil: desempenho e

OECD. Innovation for agriculture productivity and sustainability: review of Brazilian policies - working party o

gricultural policies and markets. Paris, France: OECD Conference Centre, 2014. 113p.

Rada, Analyzing Policies to Improve Agriculture Productivity Growth, Sustainably. May 2015 .
Raldes, C. Policy, Technology, and Efficiency of Brazilian Agriculture. Economic Research Report, n.

137, 43p., Jul. 2012

Ribeiro, Jose E. “Expansão Pecuária no Brasil: Efeito Poupa-Terra, Produtividade, e Emissões de Gases Efeito

Estufa." Background Paper. June, 2017.

Van der Vorst, J.G. and Snels, J., 2014. Multi-Donor Trust Fund for Sustainable Logistics (MDTF-SL): position note

Vieira Filho, J.E.R and Santos, G.R. Heterogeneidade no setor agropecuário brasileiro: contraste tecnológico. Rada World Bank Rapid Agriculture Sector Brisk Review: Towar. 2011.

ds increased integration. May 20

World Bank Junk (2016). Retaking the Path to Inclusion, Growth and Sustainability. Systematic Country Diagnostic.

World Bank (2013). Impact of Climate Change on Brazilian Agriculture. World Bank, 2013

World Bank. 2017. Rural youth employment. Report presented to the G2O. 
(4) WORLD BANKGROUP 